\title{
REVISED Fourier transform infrared spectroscopy study of ligand photodissociation and migration in inducible nitric oxide
}

\section{synthase [version 2; peer review: 2 approved]}

\author{
Michael Horn ${ }^{1}$, Karin Nienhaus¹, Gerd Ulrich Nienhaus ${ }^{1,2}$ \\ ${ }^{1}$ Karlsruhe Institute of Technology (KIT), Institute of Applied Physics, Karlsruhe, D-76131, Germany \\ ${ }^{2}$ Department of Physics, University of Illinois at Urbana-Champaign, Urbana, IL, 61801, USA
}

V2 First published: 28 Nov 2014, 3:290

https://doi.org/10.12688/f1000research.5836.1

Latest published: 12 Dec 2014, 3:290

https://doi.org/10.12688/f1000research.5836.2

\section{Abstract}

Inducible nitric oxide synthase (iNOS) is a homodimeric heme enzyme that catalyzes the formation of nitric oxide (NO) from dioxygen and Larginine (L-Arg) in a two-step process. The produced NO can either diffuse out of the heme pocket into the surroundings or it can rebind to the heme iron and inhibit enzyme action. Here we have employed Fourier transform infrared (FTIR) photolysis difference spectroscopy at cryogenic temperatures, using the carbon monoxide (CO) and NO stretching bands as local probes of the active site of iNOS. Characteristic changes were observed in the spectra of the hemebound ligands upon binding of the cofactors. Unlike photolyzed CO, which becomes trapped in well-defined orientations, as indicated by sharp photoproduct bands, photoproduct bands of NO photodissociated from the ferric heme iron were not visible, indicating that NO does not reside in the protein interior in a well-defined location or orientation. This may be favorable for NO release from the enzyme during catalysis because it reduces self-inhibition. Moreover, we used temperature derivative spectroscopy (TDS) with FTIR monitoring to explore the dynamics of $\mathrm{NO}$ and carbon monoxide (CO) inside iNOS after photodissociation at cryogenic temperatures. Only a single kinetic photoproduct state was revealed, but no secondary docking sites as in hemoglobins. Interestingly, we observed that intense illumination of six-coordinate ferrous iNOS oxy $^{-N O}$ ruptures the bond between the heme iron and the proximal thiolate to yield five-coordinate ferric iNOS oxy $_{-}$NO, demonstrating the strong trans effect of the heme-bound NO.

Keywords

iNOS, migration, ligand, heme binding , FTIR

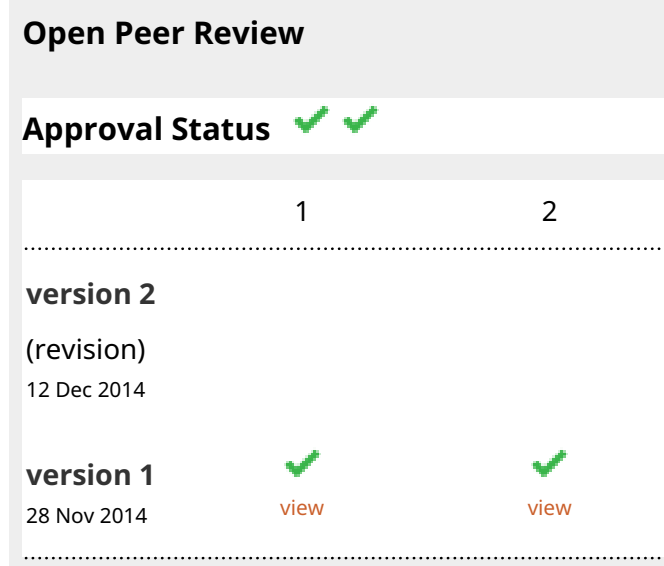

1. Pál Ormos, Biological Research Centre of the Hungarian Academy of Sciences, Szeged, Hungary

2. Marius Schmidt, University of WisconsinMilwaukee, Milwaukee, USA

Any reports and responses or comments on the article can be found at the end of the article. 
OQBiP This article is included in the Oxygen-binding and sensing proteins collection.

Corresponding author: Gerd Ulrich Nienhaus (uli@illinois.edu)

Competing interests: No competing interests were disclosed.

Grant information: This work was supported by the Deutsche Forschungsgemeinschaft (Grant Ni291/10).

The funders had no role in study design, data collection and analysis, decision to publish, or preparation of the manuscript.

Copyright: ( $) 2014$ Horn M et al. This is an open access article distributed under the terms of the Creative Commons Attribution License, which permits unrestricted use, distribution, and reproduction in any medium, provided the original work is properly cited. Data associated with the article are available under the terms of the Creative Commons Zero "No rights reserved" data waiver (CCO 1.0 Public domain dedication).

How to cite this article: Horn M, Nienhaus K and Nienhaus GU. Fourier transform infrared spectroscopy study of ligand photodissociation and migration in inducible nitric oxide synthase [version 2; peer review: 2 approved] F1000Research 2014, 3:290 https://doi.org/10.12688/f1000research.5836.2

First published: 28 Nov 2014, 3:290 https://doi.org/10.12688/f1000research.5836.1 


\section{REVISED Amendments from Version 1}

We have made the following changes to the manuscript:

1. On page 6: "In substrate free iNOS ${ }_{\text {oxy }}-\mathrm{CO}$, recombination is already maximal at $4 \mathrm{~K}$ and extends to $70 \mathrm{~K}$ " was replaced by "In substrate free iNOS ${ }_{\text {oxy }}-\mathrm{CO}$, the TDS signal is maximal at $4 \mathrm{~K}$, indicating that there is substantial rebinding already at this low temperature. Rebinding extends up to $~ 70 \mathrm{~K} "$

2. We also have added the following sentences on the same page:

"The solid contours at $\sim 2144 \mathrm{~cm}^{-1}$ in Figure $3 \mathrm{f}$ indicate a growth of this photoproduct population during the TDS measurement. Because data are taken in the dark, this can only occur via an exchange of photoproduct population from one band to another because of dynamics. Here, photoproduct population transfers from $2131 \mathrm{~cm}^{-1}$ to $\sim 2144 \mathrm{~cm}^{-1}$, and the underlying process is most likely a rotation of the CO by $180^{\circ}$ so as to attain thermal equilibrium between the two states corresponding to opposite orientations of the $\mathrm{CO}^{17 "}$.

3. The legends of Figure 3 and Figure 4 were corrected:

(a, b) w/o substrate; (c, d) with H4B; (d, e) with L-Arg;

$(f, g)$ with NOHA was replaced by

(a, b) w/o substrate; (c, d) with H4B; (e, f) with L-Arg; $(g, h)$ with NOHA

See referee reports

\section{Introduction}

Nitric oxide synthases (NOSs) are homodimeric heme enzymes that catalyze the oxidative degradation of L-arginine (L-Arg) to nitric oxide (NO) $)^{1,2}$. Three structurally similar NOS isoforms have been identified in endothelial cells (eNOS), neuronal tissues (nNOS) and in macrophages (iNOS) $)^{3}$. Different from eNOS and nNOS, iNOS is not expressed in resting cells but induced upon inflammatory and immunologic stimulation. Each NOS protomer consists of an oxygenase and a reductase domain. In the catalytic oxygenase domain $\left(\mathrm{NOS}_{\text {oxy }}\right)$, dioxygen $\left(\mathrm{O}_{2}\right)$ binds to a central heme prosthetic group, anchored to the polypeptide chain via a proximal cysteine residue (Figure 1). Its thiol sulfur atom accepts a hydrogen bond from an adjacent tryptophan residue. The substrate, L-Arg, is accommodated directly on top of the heme plane in the distal pocket; the cofactor

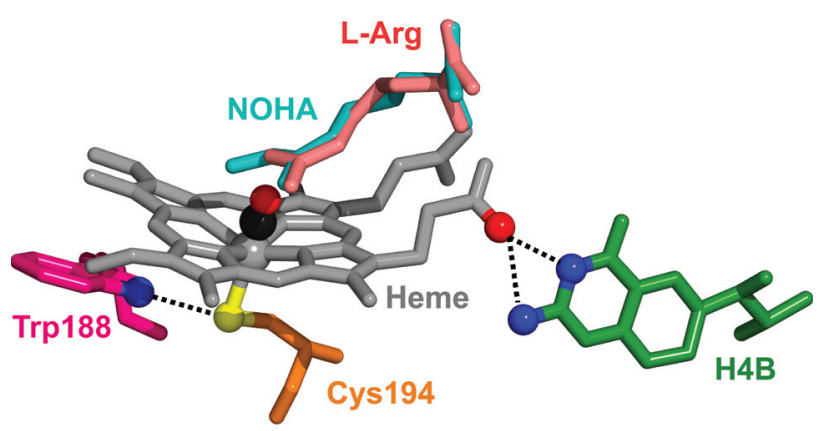

Figure 1. Schematic depiction of the iNOS ${ }_{\text {oxy }}$ active site (pdb codes 1NOD and 1DWV). The CO ligand was added for illustration. tetrahydrobiopterin, $\mathrm{H} 4 \mathrm{~B}$, binds along the side of the heme $\mathrm{e}^{4-7}$. L-Arg and $\mathrm{H} 4 \mathrm{~B}$ are linked through an extended hydrogen bonding network mediated by one of the heme propionate groups. The reductase domain, $\mathrm{NOS}_{\text {red }}$, binds flavin mononucleotide (FMN), flavin adenine dinucleotide (FAD), and reduced nicotinamide adenine dinucleotide phosphate (NADPH). It provides the electrons for the catalytic reaction proceeding in the oxygenase domain. In a first step, L-Arg is converted to N-hydroxy L-Arg (NOHA). Subsequently, NOHA is decomposed into citrulline and nitric oxide (NO). Electron transfer is enabled by calmodulin binding in the interface between the two domains ${ }^{8}$.

The NO molecule generated during enzymatic turnover can either coordinate directly to the heme iron or diffuse out of the protein into the environment. From there, it may again bind in a bimolecular process $^{9}$. Formation of the very stable ferrous NO complex results in self-inhibition of the enzyme. The probability of forming this product depends on the dissociation rate coefficient of NO from the ferric heme, the likelihood of autoreduction of the ferric NO-bound form to the ferrous derivative with its much stronger NO affinity, and the probability of oxidizing the ferrous NO-bound species to the ferric form plus nitrate by $\mathrm{O}_{2}{ }^{10}$. Deactivation of the enzyme may also occur via nitrosylation of the side chains of two cysteine residues coordinating a zinc ion in the dimer interface, which leads to irreversible dissociation into non-functional monomers ${ }^{11-14}$.

The iNOS isoform has been implicated in the pathogenesis of various diseases; so there is a growing interest in developing potent and highly selective inhibitors ${ }^{15,16}$. Their targeted design requires detailed insights into the interactions between ligand, substrate and the surrounding protein matrix. Therefore, we have investigated ligand and substrate binding in the iNOS oxygenase domain, iNOS $_{\text {oxy' }}$, by using Fourier transform infrared (FTIR) spectroscopy of the stretching vibrations of carbon monoxide $(\mathrm{CO})$ and $\mathrm{NO}$ as ligands rather than the physiological ligand $\mathrm{O}_{2}$. They are of similar size as $\mathrm{O}_{2}$, which suggests that ligand dynamics within the protein may be comparable for all three ligands. $\mathrm{CO}$ and $\mathrm{NO}$ both have excellent properties as infrared (IR) spectroscopic probes ${ }^{17}$. $\mathrm{CO}$ has proven to be an attractive heme ligand because the $\mathrm{CO}$ bond stretching vibration gives rise to strong mid-IR absorption bands that can be measured with exquisite sensitivity and precision ${ }^{17,18}$. The IR bands are fine-tuned by electrostatic interactions with the environment ${ }^{19-21}$; therefore, $\mathrm{CO}$ is frequently utilized as a local probe of protein structure and dynamics ${ }^{22}$.

In the gas phase, $\mathrm{CO}$ absorbs at $2143 \mathrm{~cm}^{-123}$. When bound to the central iron of a heme cofactor, the $\mathrm{CO}$ stretching frequency, $\mathrm{v}_{\mathrm{CO}}$, which is typically in the $1900-2000 \mathrm{~cm}^{-1}$ spectral range, is susceptible to changes in the iron-ligand bond and the local electric field due to the vibrational Stark effect ${ }^{24-29}$. There are two major contributions to the heme iron- $\mathrm{CO}$ bond, i.e., $\sigma$-donation from a weakly antibonding $5 \sigma \mathrm{MO}$ of $\mathrm{CO}$ to the iron $4 \mathrm{~s}$ and $3 \mathrm{~d}_{\mathrm{z}}^{2}$ orbitals and $\pi$-backbonding from the iron $3 \mathrm{~d}_{\mathrm{z}}$ orbitals to the strongly antibonding $\mathrm{CO} 2 \pi^{*}$ orbital $^{30}$. A positive charge located near the $\mathrm{CO}$ oxygen attracts electron density, causing a decrease in $\sigma$-donation and an increase in backbonding. Consequently, the $\mathrm{C}-\mathrm{O}$ bond order is reduced and $v_{\mathrm{CO}}$ shifts to lower values ${ }^{19-21}$. A negative charge has the opposite effect. 
After photodissociation of CO-bound heme protein samples, the stretching bands of unbound CO trapped inside a protein are found within the range from $\sim 2080$ to $\sim 2160 \mathrm{~cm}^{-118,31}$. The vibrational bands can reveal changes related to ligand relocation to other sites within the protein ${ }^{18,29,32,33}$, rotational motions of the ligand in these sites $^{25,34}$ and protein conformational changes ${ }^{35}$. Often, there are doublets of bands corresponding to opposite orientations of the $\mathrm{CO}$ at a particular transient docking site ${ }^{27,29,32,36-38}$. The bond order and, therefore, $v_{\mathrm{CO}}$ increases if the carbon atom interacts with a hydrogen bond donor, whereas an interaction with the ligand oxygen reduces both the bond strength and the stretching frequency ${ }^{29}$.

Unlike $\mathrm{CO}$, which only binds to a ferrous $\left(\mathrm{Fe}^{\mathrm{II}}\right)$ heme iron, NO may coordinate to both the ferrous and the ferric $\left(\mathrm{Fe}^{\mathrm{III}}\right)$ forms. So far, FTIR studies using NO have remained scarce because of its weaker intrinsic absorption. Furthermore, there is spectral overlap with the amide bands and ultrafast recombination of a major fraction of proteins even at very low temperatures. Therefore, only small photoproduct yields are obtained in experiments probing longer times such as FTIR, which renders experiments with ferrous NO technically challenging. Consequently, we have limited ourselves to NO binding to ferric heme in this work. For iNOS, this complex is of physiological relevance because the heme iron is in the ferric state after completion of the catalytic cycle.

Here, we have performed FTIR studies on iNOS at cryogenic temperatures, at which ligand rebinding is very slow. Thus, photoproducts induced by illumination are long-lived and can be conveniently studied by photolysis difference spectroscopy. Moreover, essentially all protein (and solvent) motions are frozen in ${ }^{39,40}$, so the ligands cannot escape to the solvent and can be observed within the protein matrix. We have combined FTIR with temperature-derivative spectroscopy (TDS $)^{41-43}$, which allows us to disentangle photolysisinduced absorption changes caused by the different types of ligand dynamics.

\section{Materials and methods}

\section{Protein expression}

The iNOS ${ }_{\text {oxy }}$ domain, with its first 65 residues deleted ( $\Delta 65$ iNOS $_{\text {oxy' }}$, referred to as iNOS $_{\text {oxy }}$ in the following), was expressed essentially

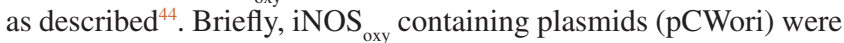
transformed into competent Escherichia coli cells (strain BL21). The cells were plated on agar in the presence of $390 \mu \mathrm{M}$ ampicillin (Carl Roth, Karlsruhe, Germany) and cultured overnight at $37^{\circ} \mathrm{C}$. A single colony was added to $150 \mathrm{ml}$ terrific broth (TB, Carl Roth) supplemented with ampicillin $(390 \mu \mathrm{M})$ and agitated for $12 \mathrm{~h}$ at $37^{\circ} \mathrm{C}$ and $250 \mathrm{rpm} .10 \mathrm{ml}$ of the overnight culture were added to 1.5 $1 \mathrm{~TB}$, containing $390 \mu \mathrm{M}$ ampicillin, and grown to an optical density of $\sim 1$ at $600 \mathrm{~nm}$. Then, the temperature was lowered to $30^{\circ} \mathrm{C}$ and $\delta$-aminolevulinic acid (44 $\mu \mathrm{M}$, Sigma-Aldrich, St. Louis, MO, USA) and hemin ( $8 \mu \mathrm{M}$, Sigma-Aldrich) were added. iNOS expression was induced by adding isopropyl $\beta$-D-1-thiogalactopyranoside (IPTG, Carl Roth) to a final concentration of $100 \mu \mathrm{M}$. After $48 \mathrm{~h}$ (fresh ampicillin was added every $16 \mathrm{~h}$ ), the cells were harvested by centrifugation for $20 \mathrm{~min}$ at $4^{\circ} \mathrm{C}$ and 2,000 rpm (swing-bucket rotor, 4-16 K, Sigma, Osterode, Germany). The cells were resuspended in lysis buffer (40 mM HEPES, 10\% glycerol (vol.), $200 \mathrm{mM} \mathrm{NaCl}$, pH 7.6, Carl Roth), mixed with 2 mg DNase (Sigma-Aldrich), and ruptured using a bead-beater (Biospec, Bartlesville, USA), filled with $0.1 \mathrm{~mm}$ (diameter) zirconia/silica beads (three treatments of 2 min each). The lysate was separated from the beads by a glass filter and loaded onto an immobilized-metal ion affinity column equilibrated with lysis buffer (Ni Sepharose 6 FastFlow, GE Healthcare). After washing with lysis buffer supplemented with increasing concentrations of imidazole $(0,10,40 \mathrm{mM}$, Sigma-Aldrich), the protein was eluted with lysis buffer containing $160 \mathrm{mM}$ imidazole. Appropriate fractions were pooled, dialyzed against water and concentrated by using Vivaspin Turbo 15 (cut-off $10 \mathrm{kDa}$ ) centrifugal concentrators (Sartorius, Göttingen, Germany). Finally, the protein was lyophilized and stored at $-20^{\circ} \mathrm{C}$.

\section{Sample preparation}

To prepare CO-ligated iNOS $_{\text {oxy }}, 12 \mathrm{mg}$ freeze-dried iNOS were slowly added to $40 \mu \mathrm{l}$ cryosolvent $(75 \% / 25 \%$ glycerol/100 mM potassium phosphate buffer (v/v), $\mathrm{pH} 7.4$, and, if so desired, supplemented with L-Arg and NOHA substrate (Sigma-Aldrich) or H4B cofactor (Sigma-Aldrich) to reach final concentrations of $200 \mathrm{mM}$ and $100 \mathrm{mM}$, respectively) and stirred under $1 \mathrm{~atm}$ CO for $60 \mathrm{~min}$. Subsequently, a two-fold molar excess of an anaerobically prepared sodium dithionite solution (Sigma-Aldrich) was added with a gastight Hamilton syringe, and the solution was stirred for another $10 \mathrm{~min}$. To remove any undissolved protein, the solution was centrifuged for $10 \mathrm{~min}$ at 13,400 rpm (Minispin centrifuge, Eppendorf, Hamburg, Germany) before loading it into the sample cell. For an NO-ligated sample, ferric iNOS ${ }_{\text {oxy }}$ was dissolved in cryosolvent and stirred under an $\mathrm{N}_{2}$ atmosphere for $1 \mathrm{~h}$. The gas phase above the sample was replaced repeatedly by $\mathrm{N}_{2}$ to efficiently remove $\mathrm{O}_{2}$. Finally, a few microliters of NO gas were added with a gas-tight syringe. NO ligation to the heme iron was confirmed by UV/vis absorption spectroscopy.

\section{Experimental setup}

A few microliters of the sample solution were sandwiched between two $\mathrm{CaF}_{2}$ windows (diameter $25.4 \mathrm{~mm}$ ) separated by a Mylar washer. The windows were mounted inside a block of oxygen-free highconductivity copper. The copper block was attached to the coldfinger of a closed-cycle helium refrigerator (model F-50, Sumitomo, Tokyo, Japan). The sample temperature was measured with a silicon temperature sensor diode and regulated in the range $3-320 \mathrm{~K}$ by a digital temperature controller (model 336, Lake Shore Cryotronics, Westerville, $\mathrm{OH}$ ). A continuous-wave, frequency-doubled Nd-YAG laser (Samba, Cobolt, Solna, Sweden), emitting up to $300 \mathrm{~mW}$ output power at $532 \mathrm{~nm}$, was used to photolyze the sample. The laser beam was split and focused with lenses on the sample from both sides. Transmission spectra were recorded on a Vertex $80 \mathrm{v}$ FTIR spectrometer (Bruker, Karlsruhe, Germany) at a resolution of $2 \mathrm{~cm}^{-1}$, using either an InSb detector (75 $\mu \mathrm{m}$ thick Mylar, 1,700 to $\left.2,300 \mathrm{~cm}^{-1}\right)$ or an MCT detector $(<5 \mu \mathrm{m}$ thick Mylar, 1,100 to $\left.2,300 \mathrm{~cm}^{-1}\right)$.

\section{FTIR photolysis difference spectroscopy}

The infrared absorption of CO and NO can be studied selectively by using photolysis difference spectroscopy, which involves measurement of IR transmission spectra, $I(v, T)$, before and after photolysis. The difference absorbance of the two spectra, $\Delta A(v, T)=$ $\log \left(I_{\text {dark }} / I_{\text {light }}\right)$, contains only features that are due to photodissociation 
of the ligand from the heme iron. The missing absorption of the heme-bound ligands (A bands) after photolysis and the corresponding absorption of the photolyzed ligands (photoproduct bands) are displayed with negative and positive amplitudes, respectively. Peak positions and fractional occupancies were determined by fits with Gaussian band shapes; they are compiled in Table 1. In the following, we use the Gaussian band positions (frequencies) at $4 \mathrm{~K}$ as a subscript to ' $A$ ' (denoting the heme-bound state) to distinguish the absorbance bands and also to refer to a particular substate of the protein.

Different illumination protocols were applied for photodissociation $^{17}$. Before starting a TDS experiment, the sample was illuminated for $10 \mathrm{~s}$ at $4 \mathrm{~K}$ to trap the photolyzed ligand close to the heme iron at the so-called primary docking site B. Alternatively, under 'slow-cool' illumination, the sample was cooled from 160 to $4 \mathrm{~K}$ at a rate $0.3 \mathrm{~K} / \mathrm{min}$ under constant laser illumination to enable the photodissociated ligands to sample alternative docking sites that may not be accessible upon photolysis at $4 \mathrm{~K}$. In both protocols, $300 \mathrm{~mW}$ laser power at $532 \mathrm{~nm}$ was used. To monitor the photodissociation kinetics, the samples were continuously illuminated for $15,000 \mathrm{~s}$ at reduced laser power $(0.3 \mathrm{~mW}$ or $10 \mathrm{~mW})$, and transmission spectra were recorded continuously. For comparison, the photolysis yield was scaled with respect to complete photodissociation with full laser power $(300 \mathrm{~mW})$.

Temperature derivative spectroscopy (TDS)

TDS, an experimental protocol designed to study thermally activated rate processes involving enthalpy barrier distributions, has been described in great detail elsewhere ${ }^{41-43}$. Briefly, a non-equilibrium state is created in the sample at low temperature, e.g., by photolysis with visible light. The integrated absorbance, $A$, of a spectral band taken at the lowest temperature represents the total photolyzed population, $N$. Subsequently, thermal relaxation of the sample back to equilibrium is recorded while the sample temperature is ramped up linearly over a few hours in the dark. One FTIR transmission spectrum is taken for every $1-\mathrm{K}$ temperature increase. In the simplest analysis, we assume that any change in integrated absorbance is due to ligand rebinding and, therefore, proportional to a population change, $\Delta N$, during acquisition of two successive spectra. TDS data are conveniently presented as two-dimensional contour plots, with solid lines indicating an absorbance increase and dashed lines a decrease. Contours are spaced logarithmically to emphasize small features.

\section{Results and discussion}

1. FTIR spectroscopy of iNOS ${ }_{\text {oxy }}$ using $\mathrm{CO}$ as an internal probe

In the following, we present 4-K FTIR photolysis difference spectra of iNOS $_{\text {oxy }}-\mathrm{CO}$ and briefly discuss the influence of substrate, substrate intermediate and cofactor on the $\mathrm{CO}$ stretching vibration and rebinding. For additional information, we refer to Jung et al. ${ }^{45}$ and Li et al. $^{46}$.

Photolysis difference spectra at $4 \mathrm{~K}$. The 4-K absorption difference spectrum of iNOS oxy $_{-} \mathrm{CO}$ displays two broad, extensively overlapping A bands at 1945 and $1959 \mathrm{~cm}^{-1}$, indicative of two active site subconformations with significant intrinsic structural heterogeneity (Figure 2a). Adding the H4B cofactor induces only small changes; the resulting spectrum can be described by a dominant $\mathrm{A}$ band centered on $1951 \mathrm{~cm}^{-1}$ and a minor one at $1924 \mathrm{~cm}^{-1}$ (Figure 2a). As H4B binds along the side of the heme ${ }^{4}$ and, thus, not in the immediate vicinity of the heme-bound $\mathrm{CO}$, it is not expected to modify $v_{\mathrm{CO}}$ to any significant extent. In contrast, the presence of L-Arg shifts the

Table 1. Positions and fractional areas of the IR stretching bands of heme-bound and photodissociated $\mathrm{CO}$ and NO ligands in iNOS ${ }_{\text {oxy }}$ samples, determined at $4 \mathrm{~K}$ with estimated experimental errors of $\pm 0.5 \mathrm{~cm}^{-1}$ and $\pm 3 \%$, respectively.

\begin{tabular}{|c|c|c|c|c|c|c|c|c|c|c|}
\hline & \multicolumn{2}{|c|}{$\begin{array}{l}\text { Heme-bound } \\
\text { CO }\end{array}$} & \multicolumn{2}{|c|}{$\begin{array}{c}\text { Photolyzed } \\
\text { CO } \\
(10 \text { s @ } 4 \text { K) }\end{array}$} & \multicolumn{2}{|c|}{$\begin{array}{c}\text { Photolyzed } \\
\text { CO } \\
\text { (Slow cool) }\end{array}$} & \multicolumn{2}{|c|}{$\begin{array}{c}\text { Heme-bound } \\
\text { NO }\end{array}$} & \multicolumn{2}{|c|}{$\begin{array}{c}\text { NO } \\
\text { Photoproduct }\end{array}$} \\
\hline & $\mathbf{c m}^{-1}$ & $\%$ & $\mathrm{~cm}^{-1}$ & $\%$ & $\mathrm{~cm}^{-1}$ & $\%$ & $\mathrm{~cm}^{-1}$ & $\%$ & $\mathbf{c m}^{-1}$ & $\%$ \\
\hline \multirow{3}{*}{ w/o substrate } & 1921 & 9 & 2124 & 55 & 2124 & 85 & 1870 & 100 & 1814 & 23 \\
\hline & 1945 & 40 & 2129 & 45 & 2132 & 15 & & & 1818 & 77 \\
\hline & 1959 & 51 & & & & & & & & \\
\hline \multirow{4}{*}{ L-Arg } & 1904 & 69 & 2120 & 28 & 2120 & 20 & 1829 & 56 & 1814 & 13 \\
\hline & 1921 & 13 & 2131 & 28 & 2131 & 34 & 1847 & 16 & 1822 & 87 \\
\hline & 1951 & 18 & 2144 & 32 & 2145 & 30 & 1870 & 28 & & \\
\hline & & & 2150 & 12 & 2150 & 16 & & & & \\
\hline \multirow{3}{*}{ NOHA } & 1903 & 13 & 2122 & 75 & 2117 & 20 & 1851 & 15 & 1814 & 30 \\
\hline & 1937 & 57 & 2133 & 19 & 2124 & 44 & 1870 & 85 & 1818 & 70 \\
\hline & 1956 & 30 & 2145 & 6 & 2133 & 36 & & & & \\
\hline \multirow{3}{*}{ H4B } & 1924 & 18 & 2124 & 75 & 2122 & 10 & 1872 & 82 & & \\
\hline & 1951 & 82 & 2133 & 25 & 2126 & 61 & 1890 & 18 & & \\
\hline & & & & & 2134 & 29 & & & & \\
\hline
\end{tabular}


main A band of iNOS ${ }_{\text {oxy }}-\mathrm{CO} / \mathrm{L}-\mathrm{Arg}$ to $1904 \mathrm{~cm}^{-1}$; smaller features are located at 1921 and $1951 \mathrm{~cm}^{-1}$ (Figure 2a). The pronounced redshift of $\mathrm{A}_{1904}$ arises from the electron-withdrawing effect of the terminal, positively charged $\mathrm{NH}_{2}^{+}$moiety of the L-Arg side chain close to the bound $\mathrm{CO}^{4}$. The position of the $\mathrm{A}_{1921}$ band is indicative of an electrostatic interaction of the $\mathrm{CO}$ dipole with a less pronounced positive partial charge, most likely the neutral terminal amino group of the L-Arg side chain.

If the reaction intermediate NOHA is present, three A bands at 1903, 1937 and $1956 \mathrm{~cm}^{-1}$ are discernable (Figure 2a). The crystal structure shows that NOHA binds in the same orientation in the active site as L-Arg, with the side chain pointing towards the heme iron ${ }^{47}$. Therefore, we suggest that, in those iNOS ${ }_{\text {oxy }}$ molecules absorbing within the $\mathrm{A}_{1937}$ band, a hydrogen bonding interaction exists between the $\mathrm{CO}$ ligand and the hydroxyl group of the NOHA side chain. $\mathrm{A}_{1903}$ is most likely associated with iNOS oxy $_{\text {molecules, }}$ in which the terminal amine of the NOHA side chain is protonated $\left(\mathrm{p} K=8.1^{48}\right)$ and points towards the heme-bound CO. The protonated NOHA has been suggested to be the catalytically active substrate intermediate ${ }^{49,50}$.

The absorption spectra of photolyzed $\mathrm{CO}$ are plotted in Figures $2 \mathrm{~b}$ (brief illumination at $4 \mathrm{~K}$ ) and $2 \mathrm{c}$ (slow-cool illumination); peak positions and relative areas are included in Table 1. For comparison, the integrated absorption in each spectral region was scaled to the same area. We note that the ratio of the integrated areas of the A and photoproduct bands is $\sim 20^{18}$.
All photoproduct spectra obtained after 10-s illumination at $4 \mathrm{~K}$ have absorption bands in the $2120-2130 \mathrm{~cm}^{-1}$ spectral range (Figure 2b). The spectrum of iNOS $_{\text {oxy }}-\mathrm{CO}$ is composed of two stretching bands at 2124 and $2129 \mathrm{~cm}^{-1}$. With H4B, photoproduct bands appear at 2124 and $2133 \mathrm{~cm}^{-1}$, indicating that the cofactor has an effect on $v_{\mathrm{CO}}$ of the unbound CO. In the presence of L-Arg, the absorption bands are centered on 2120 and $2131 \mathrm{~cm}^{-1}$, and there are two additional bands at 2144 and $2150 \mathrm{~cm}^{-1}$. Their higher stretching frequencies suggest formation of a hydrogen bond between the ligand carbon and the terminal amine group of L-Arg ${ }^{29}$. Upon NOHA binding, the photoproduct bands are centered on 2122 and $2133 \mathrm{~cm}^{-1}$. The minor absorption at $2145 \mathrm{~cm}^{-1}$ can be associated with $\mathrm{CO}$ ligands photolyzed from iNOS ${ }_{\text {oxy }} / \mathrm{NOHA}$ trapped in its $\mathrm{A}_{1903}$ conformation.

The photoproduct spectra obtained after slow-cool illumination (Figure 2c) are similar to the ones recorded after 10-s illumination (Figure 2b), suggesting that it is not possible to populate additional docking sites to any significant extent. The greatest difference is seen for iNOS ${ }_{\text {oxy }}-\mathrm{CO}$. Its photoproduct spectrum shows two well separated bands at 2124 and $2134 \mathrm{~cm}^{-1}$ rather than the non-separated doublet seen in Figure $2 \mathrm{~b}$. We also note that there is an additional shoulder at $2117 \mathrm{~cm}^{-1}$ for iNOS ${ }_{\text {oxy }}-\mathrm{CO} / \mathrm{NOHA}$.

CO rebinding in $\mathrm{NNOS}_{\text {oxy }}$. To obtain more information on the photoproduct states, TDS measurements were started at $4 \mathrm{~K}$ immediately after illumination. Figure 3 displays the contour maps obtained after 10-s illumination at $4 \mathrm{~K}$, with the absorption changes in the
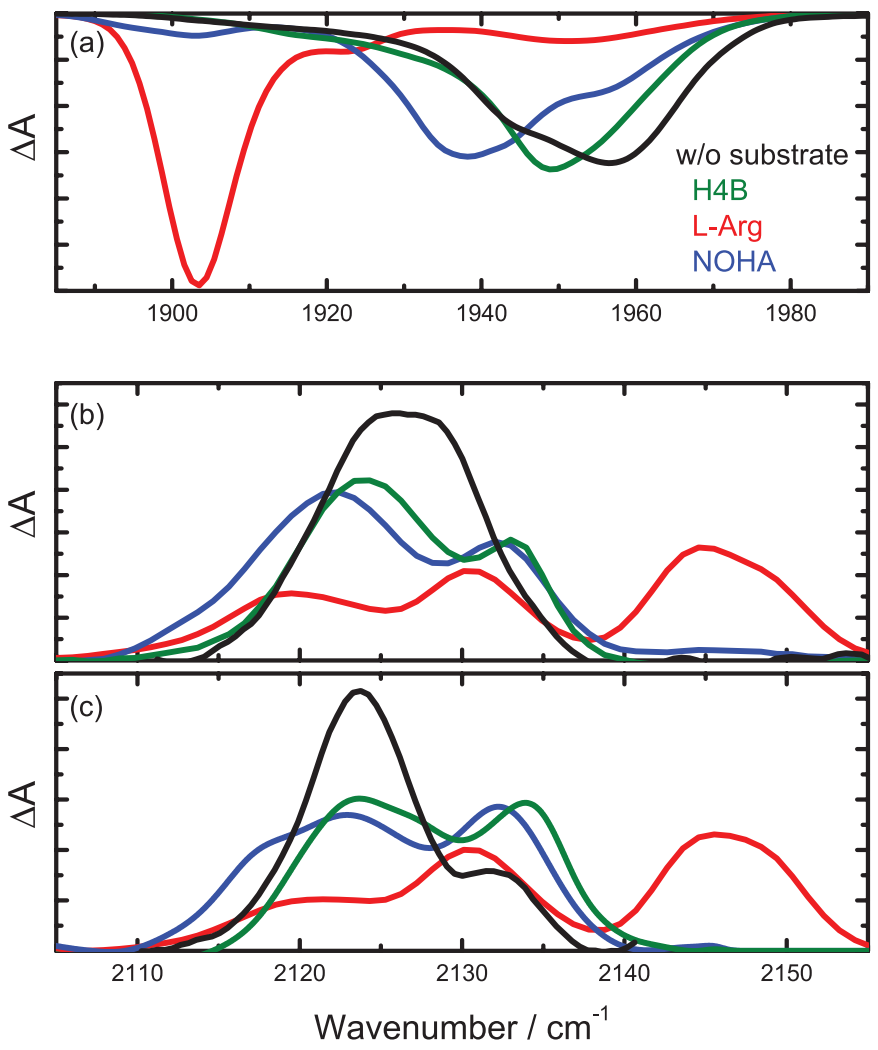

Figure 2. 4-K photolysis difference spectra of iNOS $_{\text {oxy }}$-CO. (a) Absorption of the heme-bound CO. (b) Photoproduct bands obtained after 10 -s illumination at 4 K. (c) Photoproduct bands obtained after constant illumination during slow cooling from 160 to $4 \mathrm{~K}$. 

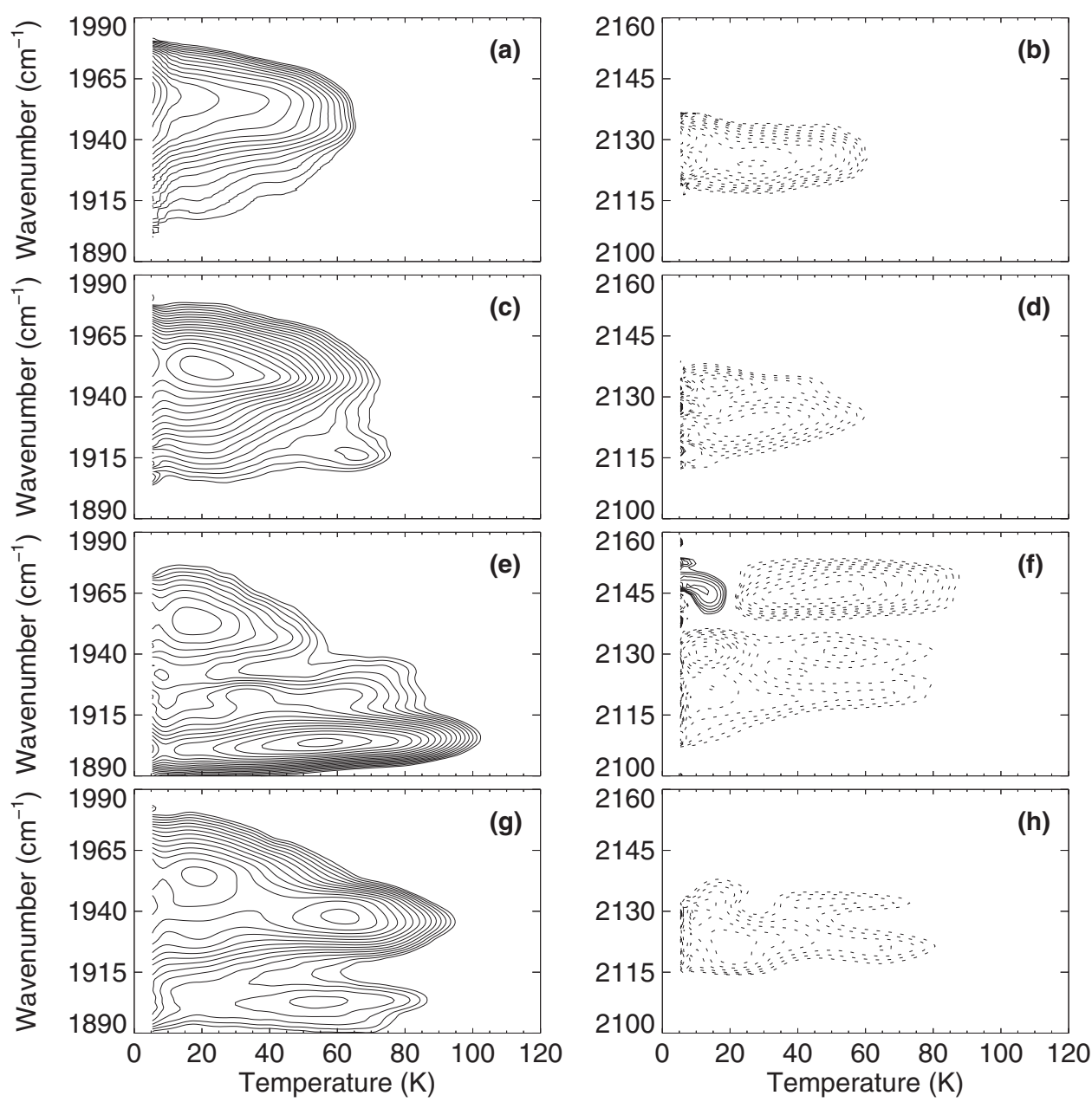

Figure 3. TDS contour maps of iNOS oxy $-\mathbf{C O}$, obtained after 10-s illumination at $\mathbf{4} \mathbf{K}$. Left column: Absorption changes in the bands of heme-bound CO. Right column: Absorption changes in the photoproduct bands. Contours are spaced logarithmically; solid and dotted lines represent increasing and decreasing absorption, respectively. iNOS ${ }_{\text {oxy }} \mathrm{CO}(\mathbf{a}, \mathbf{b})$ w/o substrate; $(\mathbf{c}, \mathbf{d})$ with $\mathrm{H} 4 \mathrm{~B} ;(\mathbf{e}, \mathbf{f})$ with L-Arg; (g, h) with $\mathrm{NOHA}$.

A bands and the photoproduct bands in the left and right columns, respectively.

All iNOS ${ }_{\text {oxy }}-\mathrm{CO}$ samples display single-step $\mathrm{CO}$ rebinding. This observation indicates that there is only a single kinetic state of the photolyzed protein-ligand complex, and the presence of sharp photoproduct bands indicates that the photolyzed ligands are trapped in transient docking sites with well-defined orientations. In substrate-free iNOS ${ }_{\text {oxy }}-\mathrm{CO}$, recombination is maximal at $4 \mathrm{~K}$, indicating that there is substantial rebinding already at this low temperature. Rebinding extends up to $\sim 70 \mathrm{~K}$ (Figure $3 \mathrm{a}, \mathrm{b}$ ). Rebinding in the dominant $\mathrm{A}_{1951}$ substate of $\mathrm{iNOS}_{\text {oxy }}-\mathrm{CO} / \mathrm{H} 4 \mathrm{~B}$ peaks at $20 \mathrm{~K}$; as in iNOS $_{\text {oxy }}-\mathrm{CO}$, the process extends to $70 \mathrm{~K}$. Only the minor $\mathrm{A}_{1924}$ subpopulation shows a focused rebinding peak at $\sim 60 \mathrm{~K}$ (Figure $3 \mathrm{c})$. The photoproduct map does not yield additional information (Figure $3 \mathrm{~d}$ ). Binding of either L-Arg or NOHA in the active site shifts $\mathrm{CO}$ rebinding to higher temperatures, suggesting that the hydrogen bonding interaction stabilizes the ligands at the transient docking site against rebinding (Figures $3 \mathrm{e}$ and $3 \mathrm{~g}$ ). Maximal rebinding in iNOS ${ }_{\text {oxy }} / \mathrm{NOHA}$, i.e., in $\mathrm{A}_{1903}$ and $\mathrm{A}_{1937}$, occurs at 50 $60 \mathrm{~K}$ (Figure $3 \mathrm{~g}$ ). The corresponding photoproduct bands are centered on 2122 and $2133 \mathrm{~cm}^{-1}$ (Figure $3 \mathrm{~h}$ ). The contours at $1950-$ $1960 \mathrm{~cm}^{-1}$ (Figure 3g) represent rebinding in the NOHA-free $\mathrm{A}_{1956}$ substate. With L-Arg anchored in the active site, $\mathrm{CO}$ ligands return to the heme iron also at $\sim 50-60 \mathrm{~K}$ (Figure $3 \mathrm{e}$ ). The corresponding photoproduct map shows a concomitant loss of the photoproduct bands at 2150,2144, 2131 and $2120 \mathrm{~cm}^{-1}$, associating these bands with $\mathrm{CO}$ molecules trapped in the vicinity of the substrate (Figure $3 \mathrm{f}$ ). A population transfer between photoproduct states due to $\mathrm{CO}$ rotation $^{32,51,52}$ is apparent from the mirror-imaged dashed and solid contours at 2131 and $2144 \mathrm{~cm}^{-1}$ at $12 \mathrm{~K}$. The solid contours at $2144 \mathrm{~cm}^{-1}$ in Figure $3 \mathrm{f}$ indicate a growth of this photoproduct population during the TDS measurement. Because data are taken in the dark, this can only occur via an exchange of photoproduct population from one band to another because of dynamics. Here, photoproduct population transfers from $2131 \mathrm{~cm}^{-1}$ to $\sim 2144 \mathrm{~cm}^{-1}$, 
and the underlying process is most likely a rotation of the $\mathrm{CO}$ by $180^{\circ}$ so as to attain thermal equilibrium between the two states corresponding to opposite orientations of the $\mathrm{CO}^{17}$.

The TDS maps after slow-cool illumination (Figure 4) show only marginal differences to the ones obtained after brief 4-K illumination (Figure 3), which confirms that the photodissociated $\mathrm{CO}$ ligands populate only a single kinetic state. Notably, after slow-cool illumination, rebinding generally occurs at slightly higher temperatures than after brief 4-K illumination. The observed slowing may be attributed to small structural changes near the active site, causing an increase of the ligand binding barrier. A similar effect was also visible in $\mathrm{MbCO}$ upon extended illumination below $40 \mathrm{~K}^{42}$ as well as in NO- and CO-ligated nitrophorin $4^{35}$.

In a typical globin protein involved in ligand transport or storage, the primary ligand docking site $\mathrm{B}$ is indispensable because it ensures efficient ligand binding to and release from the heme iron ${ }^{53}$. Incoming ligands are 'caught' in site B before the actual bond formation process occurs ${ }^{32,54}$. Upon thermal dissociation from the heme iron, ligands can remain unbound in site B for some time,

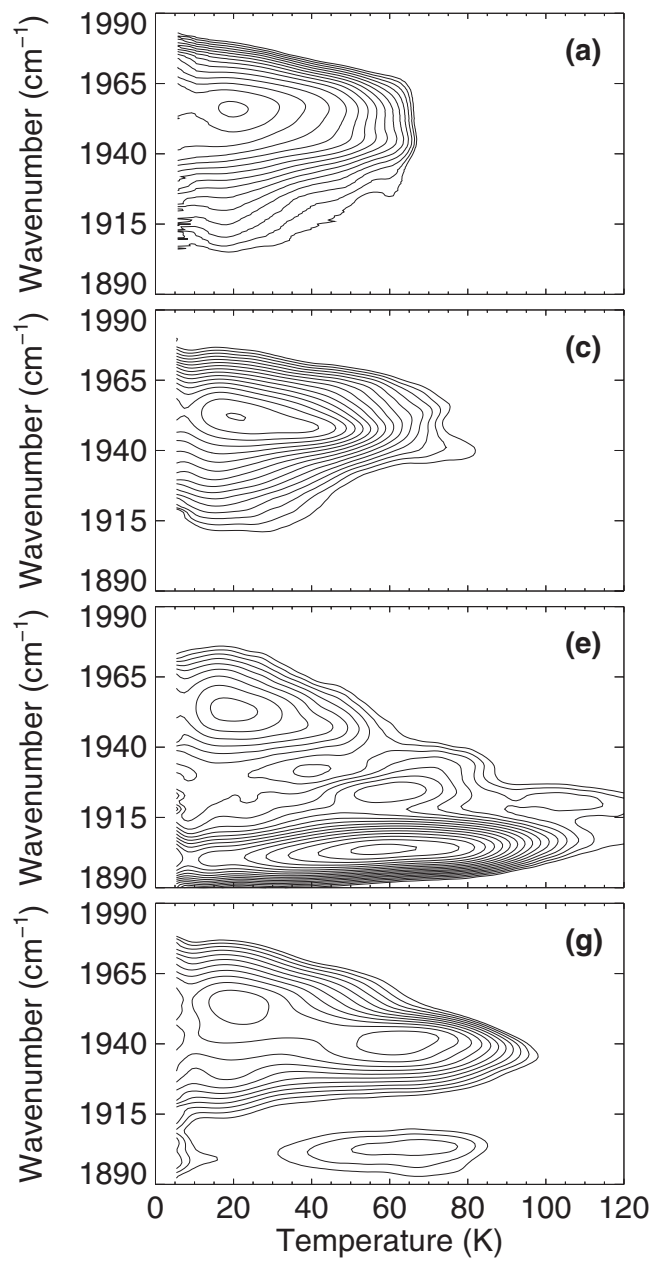

Figure 4. TDS contour maps of iNOS oxy $^{-} \mathrm{CO}$, obtained after constant illumination during slow cooling from 160 to $4 \mathrm{~K}$. Left column: Absorption changes in the bands of heme-bound CO. Right column: Absorption changes in the photoproduct bands. Contours are spaced logarithmically; solid and dotted lines represent increasing and decreasing absorption, respectively. iNOS ${ }_{\text {oxy }}$ CO (a, b) w/o substrate; (c, d) with H4B; (e, f) with L-Arg; (g, h) with NOHA.

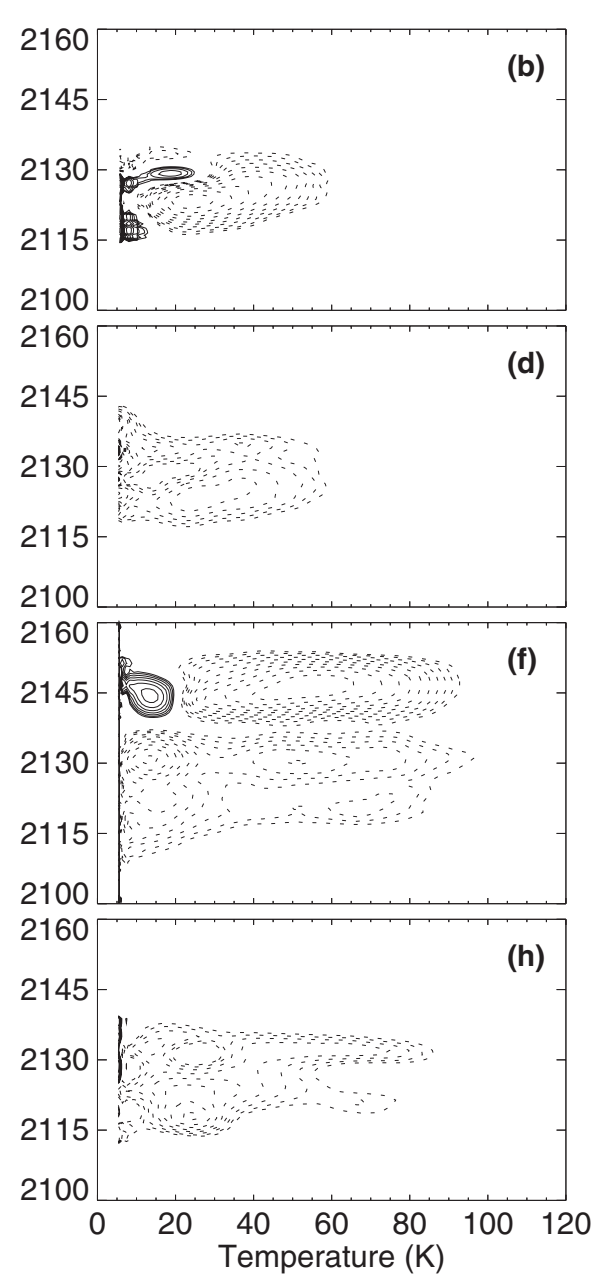

which increases their probability to escape from the protein. Without this site, they would immediately recombine with the heme iron, as is, e.g., observed for NO-transporting nitrophorin ${ }^{35}$ and modified cytochrome $\mathrm{c}^{55}$.

The catalytic reaction of iNOS requires sequential binding of two $\mathrm{O}_{2}$ molecules and efficient release of the NO product. Therefore, the B site is likely to have dual functionality. On the one hand, it allows efficient $\mathrm{O}_{2}$ binding to the heme iron. On the other hand, it ensures efficient release of the generated NO. Using $\mathrm{CO}$ as a ligand, we have shown that the B site is readily accessible for ligands photodissociated from the heme iron, both in the presence and absence of L-Arg or NOHA. The substrates stabilize the CO ligand at the transient site via hydrogen bonding. This stabilizing effect is also seen for the minor $\mathrm{A}_{1924}$ subpopulation of $\mathrm{iNOS}_{\text {oxy }} / \mathrm{H} 4 \mathrm{~B}$. Presumably, a small fraction of $\mathrm{H} 4 \mathrm{~B}$ molecules are positioned such that they can form a direct hydrogen bond.

2. FTIR spectroscopy of iNOS $_{\text {oxy }}$ using $\mathrm{NO}$ as an internal probe The NO stretching absorption is also very suitable as a local probe of the active site structure and of ligand movements within a 
protein ${ }^{17}$. Despite their similar sizes, the ligands may show different dynamics inside the protein ${ }^{56}$. For example, in myoglobin (Mb), a transient docking site on the proximal side of the heme is readily populated by $\mathrm{CO}$ but not at all by $\mathrm{NO}^{56}$. Such subtle differences could be relevant for the inhibitory effects of NO. Therefore, we have analyzed NO binding in ferric iNOS $_{\text {оху }}$ using FTIR-TDS at cryogenic temperatures.

Photolysis difference spectra at $\mathbf{4} \mathbf{K}$. Figure 5 displays $4-\mathrm{K}$ photolysis difference spectra of various ferric iNOS ${ }_{\text {oxy }}$-NO preparations. Most spectra show an A band at $1870 \mathrm{~cm}^{-1}$ associated with NO bound in an active site without bound cofactor or substrate (Table 1). In the spectrum of iNOS ${ }_{\text {oxy }}-\mathrm{NO}, \mathrm{A}_{1870}$ is rather broad, suggesting significant conformational heterogeneity at the active site. The spectrum of iNOS $_{\text {oxy }}$-NO/NOHA is very similar, dominated by the broad $\mathrm{A}_{1870}$ band; the only clear change from iNOS ${ }_{\text {oxy }}-\mathrm{NO}$ is a shoulder at $1851 \mathrm{~cm}^{-1}$. This comparison suggests that NOHA is bound only in a small subfraction reflected by the shoulder. In iNOS $_{\text {oxy }}$-NO/L-Arg, $\mathrm{A}_{1847}$ and $\mathrm{A}_{1829}$ report the binding of L-Arg. $\mathrm{A}_{1870}$ is still present due to incomplete saturation with substrate (Figure 5). Interestingly, Rousseau et al. ${ }^{2}$ could not identify any changes of $v_{\mathrm{Fe}-\mathrm{N}}$ in their resonance Raman spectra upon binding of L-Arg and even hypothesized that L-Arg does not bind to ferric iNOS oxy $_{-}$NO. With H4B anchored next to the heme, the A band is shifted to $1872 \mathrm{~cm}^{-1}$, and another absorption band emerges at $1890 \mathrm{~cm}^{-1}$.

Most of the observed spectral shifts can again be explained by backbonding ${ }^{57}$ because the ferric NO-ligated ground state, which is best described as $\mathrm{Fe}^{\mathrm{II}} \mathrm{NO}^{+}$, is isoelectronic to $\mathrm{Fe}^{\mathrm{II}} \mathrm{CO}^{58}$. The heme-bound $\mathrm{NO}$ absorbs at $1870 \mathrm{~cm}^{-1}$. L-Arg shifts $\mathrm{v}_{\mathrm{NO}}$ to lower frequencies; the $\mathrm{A}_{1829}$ and $\mathrm{A}_{1847}$ bands indicate an interaction between the NO and the positively charged and neutral terminal amino groups of the L-Arg side chain. As already observed for CO, the effect of NOHA is less pronounced; its presence is visible via a shift of the
A band to $1851 \mathrm{~cm}^{-1}$. Interestingly, the NO stretching absorption is also affected by H4B. The band shifts slightly and, in addition, it becomes rather narrow, which is indicative of a more homogeneous active site environment or restricted dynamics of the heme-bound NO due to the bound $\mathrm{H}_{4} \mathrm{~B}^{35,59}$. In 2005, Rousseau et al. ${ }^{2}$ reported that, upon H4B binding, a Raman band emerges that was assigned to the $\mathrm{Fe}-\mathrm{N}-\mathrm{O}$ bending mode, $\delta_{\mathrm{Fe}-\mathrm{N}-\mathrm{O}}$, of the ferric adduct, indicating a more homogeneous bending of the bent NO. In thiolate-ligated $\mathrm{Fe}^{\mathrm{III}} \mathrm{NO}$ adducts, NO is typically bound at an angle of $160^{\circ 60-66}$, and H4B binding next to the heme is not expected to modify this angle due to steric interactions. It may, however, restrict its librational dynamics around this angle, possibly because of the increased heme distortion caused by $\mathrm{H}_{4} \mathrm{~B}^{67,68}$. The additional band at $1890 \mathrm{~cm}^{-1}$ may indicate partial occupancy of a water molecule in the active site ${ }^{62}$.

The photoproduct bands, displayed in Figure 5 with positive amplitudes, are in the $1810-1830 \mathrm{~cm}^{-1}$ spectral range and, thus, redshifted by only $\sim 50 \mathrm{~cm}^{-1}$ from those of the heme-bound NO (Table 1). For iNOS ${ }_{\text {oxy }}-\mathrm{NO} / \mathrm{L}-\mathrm{Arg}$, the photoproduct and A bands even overlap. Their decomposition (details are discussed below) yields a narrow photoproduct band at $1814 \mathrm{~cm}^{-1}$ and a broad feature at $1822 \mathrm{~cm}^{-1}$. iNOS $_{\text {oxy }}-\mathrm{NO}$ and iNOS oxy -NO/NOHA show two photoproduct bands at 1814 and $1818 \mathrm{~cm}^{-1}$. Interestingly, these bands are about as strong as the A bands, which strongly suggests that they do not represent unbound NO trapped in a transient docking site but rather hemebound NO with restricted librational freedom.

In contrast to all other samples, the iNOS ${ }_{\text {oxy }}-\mathrm{NO} / \mathrm{H} 4 \mathrm{~B}$ photoproduct spectrum reveals only a very weak feature at $\sim 1818 \mathrm{~cm}^{-1}$. This finding may be explained by a photolyzed NO that cannot be trapped in well-defined orientations. As a result, the stretching absorption becomes extremely broad and hardly distinguishable from the background. A similar effect was observed for NO in the primary photoproduct site B of ferric $\mathrm{Mb}^{56}$.

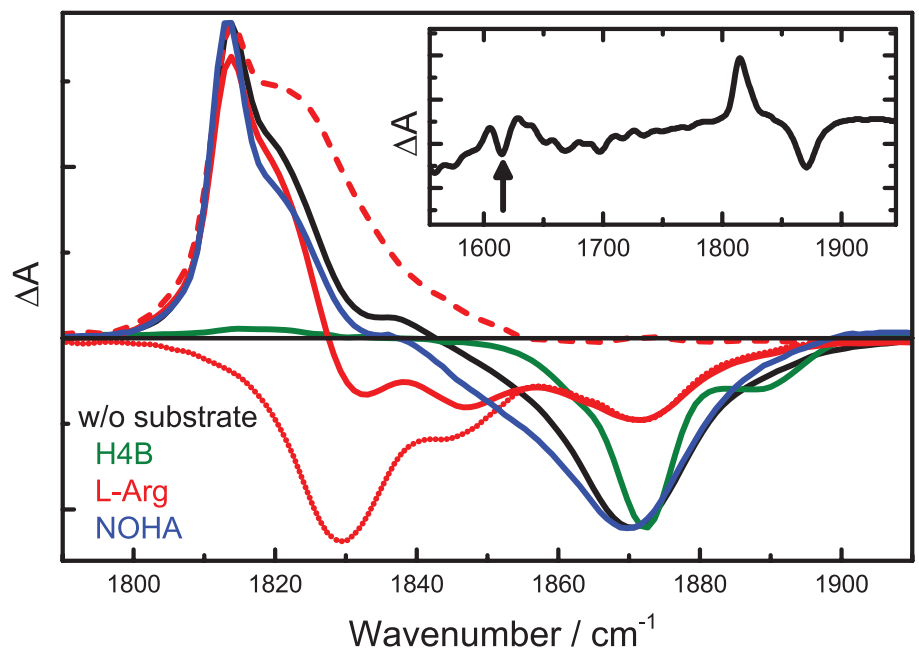

Figure 5. 4-K photolysis difference spectra of iNOS $_{\text {oxy }}$-NO. The stretching bands of heme-bound NO (NO after laser illumination at $300 \mathrm{~mW}$ ) are plotted with negative (positive) amplitude. A bands of the NOHA spectrum were scaled independently of photoproducts (factor 2.07) to match the $\mathrm{A}$ bands of the spectrum without substrate. Dotted line: 4-K photolysis difference spectrum of iNOS ${ }_{\text {oxy }}-\mathrm{NO} / \mathrm{L}-\mathrm{Arg}_{\mathrm{B}}$, obtained upon illumination at $0.3 \mathrm{~mW}$. Dashed line: iNOS ${ }^{-} \mathrm{NO} / \mathrm{L}$-Arg photoproduct spectrum (obtained by calculating the difference between the two iNOS $_{\text {oxy }}-\mathrm{NO} / \mathrm{L}-$ Arg spectra). Inset: extended $4-\mathrm{K}$ photolysis difference spectrum of iNOS oxy $_{-}-\mathrm{NO}$. 
NO rebinding in ferric iNOS ${ }_{\text {oxy }}$. To gain additional information on the peculiar, strongly absorbing NO photoproduct bands, TDS experiments were started immediately after illuminating NOligated samples at $4 \mathrm{~K}$. Figure 6 displays the absorption changes in the A bands and in the photoproduct bands with solid and dotted lines, respectively. The contour maps obtained after slow cool illumination (not shown) are essentially identical, as for the CO-ligated samples.

In iNOS ${ }_{\text {oxy }}$-NO, NO rebinding in $\mathrm{A}_{1870}$ starts already at the lowest temperatures (Figure $6 \mathrm{a}$ ) and extends to $\sim 90 \mathrm{~K}$. The decay of the photoproduct, however, occurs predominantly between 80 and $120 \mathrm{~K}$, indicating that these bands cannot be associated with NO ligands photolyzed from the ferric heme iron, as reported by the $\mathrm{A}_{1870}$ band. Apparently, laser illumination produces a photoproduct band from another NO species in the sample. The TDS map of $\mathrm{iNOS}_{\text {oxy }}-\mathrm{NO} /$ NOHA (Figure 6d) shows essentially the same features. It is likewise evident that NO rebinding is complete below $80 \mathrm{~K}$, whereas the strange photoproduct feature disappears in the temperature range $80-120 \mathrm{~K}$. In iNOS ${ }_{\text {oxy }}-\mathrm{NO} / \mathrm{H} 4 \mathrm{~B}$ (Figure 6b), NO rebinding at the ferric iron also starts at $4 \mathrm{~K}$. In a subpopulation, recombination

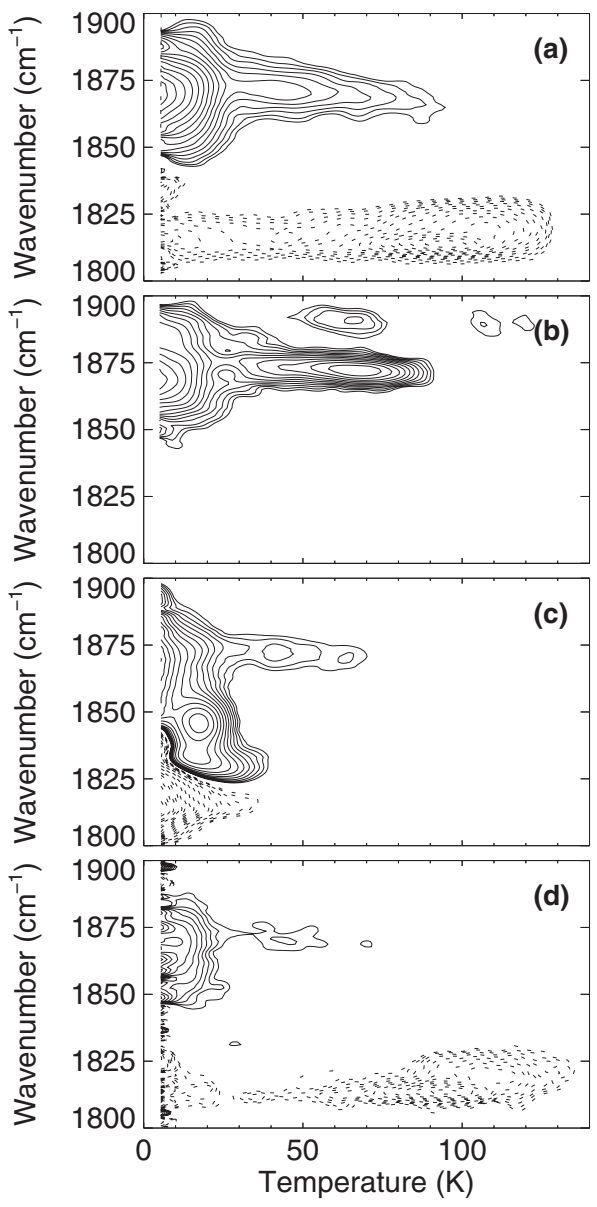

Figure 6. TDS contour maps of iNOS ${ }_{\text {oxy }}$-NO, obtained after 30-min illumination at $\mathbf{4} \mathbf{K}$. iNOS ${ }_{\text {oxy }}-\mathrm{NO}(\mathbf{a})$ w/o substrate; (b) with $\mathrm{H} 4 \mathrm{~B}$; (c) with L-Arg; (d) with NOHA. Contours are spaced logarithmically; solid and dotted lines represent increasing and decreasing absorption, respectively. peaks at $\sim 65 \mathrm{~K}$; absorption changes of photoproducts are too small to be detected. NO rebinding in the L-Arg-bound $\mathrm{A}_{1829}$ and $\mathrm{A}_{1847}$ substates occurs mainly below $30 \mathrm{~K}$, concomitantly with the decay of the photoproduct (Figure 6c). The apparent maximum in the contours at $15 \mathrm{~K}$ and $\sim 1850 \mathrm{~cm}^{-1}$ is artificial and results from the superposition of the A bands and the photoproduct bands (compare Figure 5). Recombination in the substrate-free $A_{1870}$ fraction of the sample is maximal at $4 \mathrm{~K}$ and extends out to $\sim 70 \mathrm{~K}$, consistent with the data shown in Figure 6a.

In summary, rebinding of NO to the ferric heme of $\mathrm{iNOS}_{\text {oxy }}$ is a one-step process. The corresponding photoproduct bands, i.e., the absorption bands of NO photodissociated from the ferric heme, were not identifiable. Presumably, NO is bound only weakly within the protein, without any well-defined orientation and without any additional stabilization via hydrogen bonding interactions to the substrate or the cofactor. As a consequence, the NO has a broad stretching absorption that cannot be distinguished from the background. Note that, if the photoproduct bands were masked by the strong bands at $\sim 1820 \mathrm{~cm}^{-1}$, they should have become visible in the spectrum of iNOS ${ }_{\text {oxy }}-\mathrm{NO} / \mathrm{H} 4 \mathrm{~B}$ (Figure 5).

Identification of the iNOS ${ }_{o x y}-\mathrm{NO}$ photoproduct. The TDS data in Figure 5 clearly prove that the strong absorption bands at $\sim 1820 \mathrm{~cm}^{-1}$ are not generated by photodissociation of $\mathrm{NO}$ bound to ferric heme, absorbing at $\sim 1870 \mathrm{~cm}^{-1}$. To identify the corresponding pre-illumination states, we screened the 4-K FTIR photolysis difference spectrum of iNOS oxy $_{\text {y }}$ NO from 1,100 to $2,300 \mathrm{~cm}^{-1}$ and detected a band at $1616 \mathrm{~cm}^{-1}$, which we tentatively associate with a six-coordinate (6C) ferrous NO adduct (Figure 5, inset). This assignment is supported by the $v_{\mathrm{NO}}$ of $1591 \mathrm{~cm}^{-1}$ reported for $6 \mathrm{C}$ ferrous $\mathrm{P} 450_{\mathrm{cam}^{-}}$ $\mathrm{NO}^{69}$. Praneeth et al. ${ }^{70}$ also computed frequencies in this range, $\mathrm{v}_{\mathrm{NO}}$ $=1617 \mathrm{~cm}^{-1}$ and $v_{\mathrm{NO}}<1600 \mathrm{~cm}^{-1}$ for thiophenolate- and alkylthiolate-heme complexes, respectively, using density functional theory calculations on ferrous, thiolate-coordinated porphyrin model systems.

The admixture of a ferrous NO species in our samples does not come as a surprise. Ferric iNOS ${ }_{\text {oxy }}-\mathrm{NO}$ is unstable and spontaneously converts to a ferrous $6 \mathrm{C}$ NO-ligated species. This conversion may take place during loading and cooling of an FTIR sample, which typically takes $\sim 2 \mathrm{~h}$. This species may subsequently evolve further to a five-coordinate $(5 \mathrm{C})$ complex by dissociation of the thiolate ligand on time scales of minutes to hours, depending on the iNOS $_{\text {oxy }}$ oligomerization state ${ }^{67,71-73}$. Here, we can safely exclude formation of significant amounts of $5 \mathrm{C}$ ferrous iNOS ${ }_{\text {oxy }}-\mathrm{NO}$ because we have not observed the characteristic IR bands of this species at $\sim 1670 \mathrm{~cm}^{-153}$.

NO photodissociation from the $6 \mathrm{C}$ adduct is not expected to generate $\mathrm{NO}$ photoproduct bands that are of similar strength as the original $\mathrm{A}_{1616}$ band. Therefore, there must be yet another species responsible for the strong absorption at $\sim 1820 \mathrm{~cm}^{-1}$. Perhaps, light-induced breakage of the iron-sulfur rather than the iron-NO bond could lead to an alternative photoproduct, considering the strong trans effect exerted by the $\mathrm{NO}$ in $6 \mathrm{C}$ ferrous heme $\mathrm{NO}$ adducts ${ }^{66}$. Indeed, Ibrahim et $a l .{ }^{74}$ had noticed earlier that laser light passing through solution samples of $6 \mathrm{C}$ ferrous model porphyrins adducts during resonance 
Raman measurements was sufficient to photodissociate the axial thiolate base trans to the $\mathrm{NO}^{75}$. This effect could be suppressed by lowering the temperature to $77 \mathrm{~K}$ and reducing the laser power. Accordingly, we have illuminated the $\mathrm{iNOS}_{\text {oxy }}-\mathrm{NO} / \mathrm{L}-\mathrm{Arg}$ sample at low laser intensity $(0.3 \mathrm{~mW}$ at $532 \mathrm{~nm})$. This power was still sufficient to photodissociate the NO from the $6 \mathrm{C}$ ferric heme adduct (dotted line in Figure 5), photoproduct bands at $\sim 1820 \mathrm{~cm}^{-1}$, however, did not emerge, confirming that the photoproduct was not formed. Therefore, we propose that illumination of $6 \mathrm{C}$ ferrous iNOS ${ }_{\text {оху }}-\mathrm{NO}$ with sufficient laser power leads to rupture of the bond between the iron and the proximal Cys 194 thiolate, leaving behind a $5 \mathrm{CiNOS}_{\text {oxy }}$ - $^{-}$ NO. Because the NO is still bound to the heme iron, the intensity of the IR bands at $\sim 1820 \mathrm{~cm}^{-1}$ is comparable to that of other A bands $\mathrm{s}^{25,34}$. The NO stretching frequency of the $5 \mathrm{C}$ adduct indicates that the ligand is coordinated to a ferric iron, so that the Cys194 sulfur is negatively charged after photodissociation. Similar NO stretching frequencies were reported for an isolated $5 \mathrm{C}$ ferric heme nitrosyl complex $\left(v_{\mathrm{NO}}=1842 \mathrm{~cm}^{-176}\right)$ and for NO-ligated porphyrins with phenyl $\left(v_{\mathrm{NO}}=1825 \mathrm{~cm}^{-1}\right)$ and pentafluorophenyl $\left(\mathrm{v}_{\mathrm{NO}}=1859 \mathrm{~cm}^{-1}\right)$ substituents on the four meso positions ${ }^{77}$. If the laser power is sufficiently high $(300 \mathrm{~mW})$, it is even possible to photodissociate the NO from the $5 \mathrm{C}$ ferric iNOS ${ }_{\text {oxy }}-\mathrm{NO}$, leaving behind a four-coordinate, 'naked' heme as a 'secondary photoproduct' (Figure 7a).

L-Arg binding in the active site lowers the yield of ferric $5 \mathrm{C}$ iNOS ${ }_{\text {oxy }}{ }^{-}$ NO upon laser illumination (Figures $7 \mathrm{a}$ and c) and favors reformation of the iron-sulfur bond as soon as the laser is switched off (Figures $7 b$ and d). This effect may result from the competition between the NO ligand and the thiolate for $\sigma$ charge donation to the heme iron; the higher the donation, the stronger the bond to the donor and the weaker the bond to the opposing heme ligand. The $\sigma$ donor strength of the thiolate is altered by hydrogen bonding interactions to the sulfur atom ${ }^{66}$. Using sulfur K-edge $\mathrm{x}$-ray absorption spectroscopy and density functional theory calculations, Dey et al. ${ }^{78}$ showed that each hydrogen bond reduces the electron-donating power of the thiolate sulfur. The NO electron donor ability and, therefore, its repulsive trans effect can be reduced by interactions that draw electron density away from the $\mathrm{NO}^{79,80}$, here by the hydrogen bonding interaction with L-Arg, so that the axial iron-sulfur bond is stabilized.

We also note that $6 \mathrm{C}$ ferrous iNOS ${ }_{\text {oxy }}-\mathrm{NO}$ is not stable in the presence of $\mathrm{H} 4 \mathrm{~B}$ but spontaneously oxidizes to the ferric form ${ }^{46}$. Consequently, the yield of the $5 \mathrm{C}$ adduct is negligible, as is indicated by the low intensity of the absorption bands (Figure 5).

Ferric 5C iNOS ${ }_{\text {oxy }}-\mathrm{NO}$. In view of the competition between the NO ligand and the thiolate for $\sigma$ charge donation to the heme iron, one should expect $v_{\mathrm{NO}}$ of the $5 \mathrm{C}$ photoproduct lacking the thiolate ligand to be blue-shifted with respect to $v_{\mathrm{NO}}$ of the $6 \mathrm{C}$ adduct because the repulsive trans effect of the thiolate has been removed. Experimentally, however, the opposite behavior is observed (Figure 5). To resolve this apparent discrepancy, one has to consider that the $5 \mathrm{C}$ ferric form originates from a $6 \mathrm{C}$ ferrous species, in which the $\mathrm{NO}$ is typically bound at an angle of $\sim 140^{\circ}$. In the corresponding $6 \mathrm{C}$ ferric derivatives, the $\mathrm{Fe}-\mathrm{N}-\mathrm{O}$ angle is normally $\sim 160^{\circ}$. At cryogenic temperatures, the dynamics of the protein matrix is completely arrested ${ }^{39,40}$.

Consequently, the NO is held in the strongly bent (lower angle) orientation of the 6C ferrous form. Based on DFT calculations, Linder et al.$^{81}$ reported that reducing the angle from $160^{\circ}$ to $150^{\circ}$ shifts $v_{\mathrm{NO}}$ in $5 \mathrm{C}$ model porphyrins from 1897 to $1857 \mathrm{~cm}^{-1}$. Therefore, we suggest that the low $v_{\text {NO }}$ of the $5 \mathrm{C}$ form is caused by NO binding at a small angle. We note that the similar $v_{\text {NO }}$ in $5 \mathrm{C}$ and $6 \mathrm{C}$ ferric iNOS ${ }_{\text {oxy }}-$ $\mathrm{NO} / \mathrm{L}-\mathrm{Arg}$ implies that the bound substrate controls the angle at which the NO binds. Apparently, steric constraints override the bending induced by the trans effects.

Finally, we point out that, in contrast to the photo-induced $6 \mathrm{C}$ ferric $\rightarrow 5 \mathrm{C}$ ferric transition observed in the FTIR experiments at cryogenic temperatures, the spontaneous conversion of the $6 \mathrm{C}$ ferric NO-bound iNOS ${ }_{\text {oxy }}$ derivative at physiological temperatures involves two NO molecules and yields a $5 \mathrm{C}$ ferrous species ${ }^{71,72,82}$. After binding the first $\mathrm{NO}$, the ferric $6 \mathrm{C}$ iNOS $_{\text {oxy }}-\mathrm{NO}$ reacts with a second ligand to yield $6 \mathrm{C}$ ferrous iNOS $_{\text {oxy }}-\mathrm{NO}$. This complex
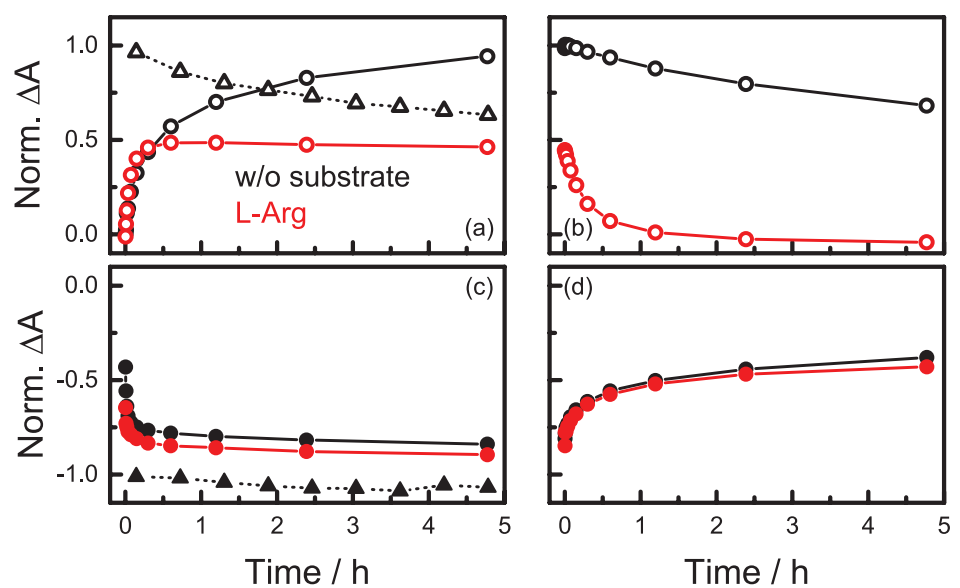

Figure 7. Temporal development of the integrated absorbance of the bands of $5 \mathrm{C}$ ferric iNOS ${ }_{\text {oxy }}-\mathrm{NO}$ (open symbols) and $6 \mathrm{C}$ ferric iNOS ${ }_{\text {oxy }}-\mathrm{NO}$ (filled symbols) (a, c) during constant illumination at $4 \mathrm{~K}$ (circles: $10 \mathrm{~mW}, 532 \mathrm{~nm}$; triangles: $300 \mathrm{~mW}, 532 \mathrm{~nm}$ ) and (b, d) after the laser was switched off. Black: iNOS ${ }_{\text {oxy }}-\mathrm{NO}$; red: iNOS ${ }_{\text {oxy }}-\mathrm{NO} / \mathrm{L}-\mathrm{Arg}$. 
immediately converts to the $5 \mathrm{C}$ form and a nitrosonium ion $\left(\mathrm{NO}^{+}\right)$. The ion may diffuse towards the zinc binding site and nitrosylate one of the Cys residues involved in coordinating the zinc.

\section{Dataset 1. Fourier transform infrared photolysis difference} spectra of $\mathrm{CO}$ - and NO-ligated inducible nitric oxide synthase

\section{http://dx.doi.org/10.5256/f1000research.5836.d39481}

Detailed information on the dataset can be found in the text file "Raw data legend".

\section{Conclusions}

FTIR spectroscopy at cryogenic temperatures, especially in combination with sophisticated illumination and data acquisition temperature protocols, provides quantitative data on protein-ligand interactions. Our FTIR-TDS studies on NOS $_{\text {oxy }}$ have shown that $\mathrm{CO}$ and NO rebinding involve only a single transient state in NOS $_{\text {oxy }}$ The CO is stabilized in well-defined orientations at the docking site by hydrogen bonding interactions and, therefore, gives rise to rather narrow photoproduct bands. In contrast, photoproduct bands associated with the photolyzed NO cannot be resolved. The NO appears to be trapped in less specific orientations, which may favor the release of this ligand. Under physiological conditions, release of the generated NO from the protein is facilitated.

Upon illumination of $6 \mathrm{C}$ ferrous iNOS ${ }_{\text {oxy }}$-NO at cryogenic temperatures, a $5 \mathrm{C}$ ferric $\mathrm{NO}$ adduct was identified, providing direct evidence for light-induced breakage of the iron-thiolate bond. Future studies along these lines are likely to contribute to a better understanding of functional processes in which the NO ligand is involved.

\section{Data availability}

F1000Research: Dataset 1. Fourier transform infrared photolysis difference spectra of CO- and NO-ligated inducible nitric oxide synthase, 10.5256/f1000research.5836.d39481 ${ }^{83}$

\section{Author contributions}

Michael Horn performed the experiments. All authors have contributed to planning the experiments and analyzing the results. All authors were involved in writing and editing the draft of this manuscript. All authors have read and approved the final version.

\section{Competing interests}

No competing interests were disclosed.

\section{Grant information}

This work was supported by the Deutsche Forschungsgemeinschaft (Grant Ni291/10). We acknowledge support by Deutsche Forschungsgemeinschaft and Open Access Publishing Fund of Karlsruhe Institute of Technology.

The funders had no role in study design, data collection and analysis, decision to publish, or preparation of the manuscript.
1. Li HY, Poulos TL: Structure-function studies on nitric oxide synthases. J Inorg Biochem. 2005; 99(1): 293-305. PubMed Abstract | Publisher Full Tex

2. Rousseau DL, Li D, Couture $M$, et al:: Ligand-protein interactions in nitric oxide synthase. J Inorg Biochem. 2005; 99(1): 306-323. PubMed Abstract | Publisher Full Text

3. Stuehr DJ: Mammalian nitric oxide synthases. Biochim Biophys Acta. 1999 1411(2-3): 217-230. PubMed Abstract | Publisher Full Text

4. Crane BR, Arvai AS, Ghosh DK, et al.: Structure of nitric oxide synthase oxygenase dimer with pterin and substrate. Science. 1998; 279(5359): 2121-2126. PubMed Abstract | Publisher Full Text

5. Li H, Raman CS, Glaser CB, et al:: Crystal structures of zinc-free and -bound heme domain of human inducible nitric-oxide synthase. Implications for dime stability and comparison with endothelial nitric-oxide synthase. J Biol Chem. 1999; 274(30): 21276-21284. PubMed Abstract | Publisher Full Text

6. Raman CS, Li H, Martasek $\mathrm{P}$, et al:: Crystal structure of nitric oxide synthase heme domains. J Inorg Biochem. 1999; 74: 44-44.

7. Fischmann TO, Hruza A, Niu XD, et al.: Structural characterization of nitric oxide synthase isoforms reveals striking active-site conservation. Nat Struct Biol. 1999; 6(3): 233-242. PubMed Abstract | Publisher Full Text

8. Abu-Soud HM, Yoho LL, Stuehr DJ: Calmodulin controls neuronal nitric-oxide synthase by a dual mechanism. Activation of intra- and interdomain electron transfer. J Biol Chem. 1994; 269(51): 32047-32050. PubMed Abstract

9. Abu-Soud $\mathrm{HM}$, Ichimori $\mathrm{K}, \mathrm{Nakazawa} \mathrm{H}$, et al:: Regulation of inducible nitric oxide synthase by self-generated NO. Biochemistry. 2001; 40(2): 6876-6881. PubMed Abstract | Publisher Full Text

10. Santolini J, Adak S, Curran CM, et al:: A kinetic simulation model that describes catalysis and regulation in nitric-oxide synthase. J Biol Chem. 2001; 276(2):
1233-1243.

PubMed Abstract | Publisher Full Text

11. Mitchell DA, Erwin PA, Michel T, et al:: S-Nitrosation and regulation of inducible nitric oxide synthase. Biochemistry. 2005; 44(12): 4636-4647. PubMed Abstract | Publisher Full Text

12. Smith BC, Fernhoff NB, Marletta MA: Mechanism and kinetics of inducible nitric oxide synthase auto-S-nitrosation and inactivation. Biochemistry. 2012; 51(5): 1028-1040.

PubMed Abstract | Publisher Full Text | Free Full Text

13. Rosenfeld RJ, Bonaventura J, Szymczyna BR, et al:: Nitric-oxide synthase forms N-NO-pterin and S-NO-cys: implications for activity, allostery, and regulation. J Biol Chem. 2010; 285(41): 31581-31589.

PubMed Abstract | Publisher Full Text | Free Full Text

14. Ravi K, Brennan LA, Levic S, et al:: S-nitrosylation of endothelial nitric oxide synthase is associated with monomerization and decreased enzyme activity. Proc Natl Acad Sci U S A. 2004; 101(8): 2619-2624. PubMed Abstract | Publisher Full Text | Free Full Text

15. Crane BR, Arvai AS, Gachhui R, et al:: The structure of nitric oxide synthase oxygenase domain and inhibitor complexes. Science. 1997; 278(5337): 425-431. PubMed Abstract | Publisher Full Text

16. Garcin ED, Arvai AS, Rosenfeld RJ, et al.: Anchored plasticity opens doors for selective inhibitor design in nitric oxide synthase. Nat Chem Biol. 2008; 4(11): $700-707$.

PubMed Abstract | Publisher Full Text | Free Full Text

17. Nienhaus K, Nienhaus GU: Ligand dynamics in heme proteins observed by Fourier transform infrared spectroscopy at cryogenic temperatures. Methods Enzymol. 2008; 437: 347-378. PubMed Abstract | Publisher Full Text

18. Nienhaus K, Nienhaus GU: Ligand dynamics in heme proteins observed by Fourier transform infrared-temperature derivative spectroscopy. Biochim Biophys Acta. 2011; 1814(8): 1030-1041. PubMed Abstract | Publisher Full Text 
19. Vogel KM, Kozlowski PM, Zgierski MZ, et al.: Determinants of the FeXO (X $=\mathbf{C}$ $\mathrm{N}, \mathrm{O})$ vibrational frequencies in heme adducts from experiment and density functional theory. J Am Chem Soc. 1999; 121(43): 9915-9921.

Publisher Full Text

20. Li T, Quillin ML, Phillips GN Jr, et al:: Structural determinants of the stretching frequency of CO bound to myoglobin. Biochemistry. 1994; 33(6): 1433-1446. PubMed Abstract | Publisher Full Text

21. Ray GB, Li XY, Ibers JA, et al.: How far can proteins bend the FeCO unit? Distal polar and steric effects in heme proteins and models. J Am Chem Soc. 1994; 116(1): 162-176

Publisher Full Tex

22. Spiro TG, Ibrahim M, Wasbotten IH: Chapter 4 - CO, NO, and 02 as Vibrationa Probes of Heme Protein Active Sites. in The Smallest Biomolecules: Diatomics and their Interactions with Heme Proteins (Ghosh, A. ed.), Elsevier, Amsterdam. 2008; pp 95-123.

Publisher Full Text

23. Ewing GE: Infrared Spectra of Liquid and Solid Carbon Monoxide. J Chem Phys. 1962; 37(10): 2250

Publisher Full Text

24. Franzen S, Wallace-Williams SE, Shreve AP: Heme charge-transfer band III is vibronically coupled to the Soret band. J Am Chem Soc. 2002; 124(24): 7146-7155. PubMed Abstract | Publisher Full Text

25. Kriegl JM, Nienhaus $\mathrm{K}$, Deng $\mathrm{P}$, et al:: Ligand dynamics in a protein internal cavity. Proc Natl Acad Sci U S A. 2003; 100(12): 7069-7074.

PubMed Abstract | Publisher Full Text | Free Full Text

26. Park ES, Andrews SS, Hu RB, et al.: Vibrational stark spectroscopy in proteins: A probe and calibration for electrostatic fields. J Phys Chem B. 1999; 103(45): 9813-9817.

Publisher Full Text

27. Park ES, Boxer SG: Origins of the sensitivity of molecular vibrations on electric fields: Carbonyl and Nitrosyl Stretches in Model Compounds and Proteins. J Phys Chem. 2002; 106(22): 5800-5806.

Publisher Full Tex

28. Park ES, Thomas MR, Boxer SG: Vibrational Stark Spectroscopy of NO bound to Heme: Effects of Protein Electrostatic fields on the NO Stretch Frequency. $J$ Am Chem Soc. 2000; 122(49): 12297-12303.

Publisher Full Text

29. Nienhaus $\mathrm{K}$, Olson JS, Franzen S, et al.: The origin of stark splitting in the initia photoproduct state of MbCO. J Am Chem Soc. 2005; 127(1): 40-41. PubMed Abstract | Publisher Full Text

30. Kushkuley B, Stavrov SS: Theoretical study of the distal-side steric and electrostatic effects on the vibrational characteristics of the FeCO unit of the carbonylheme proteins and their models. Biophys J. 1996; 70(3): 1214-1229. PubMed Abstract | Publisher Full Text | Free Full Text

31. Nutt DR, Meuwly M: Theoretical investigation of infrared spectra and pocket dynamics of photodissociated carbonmonoxy myoglobin. Biophys J. 2003; 85(6): 3612-3623.

PubMed Abstract | Publisher Full Text | Free Full Text

32. Nienhaus K, Deng P, Kriegl JM, et al.: Structural dynamics of myoglobin: effect of internal cavities on ligand migration and binding. Biochemistry. 2003; 42(32): 9647-9658.

PubMed Abstract | Publisher Full Text

33. Nienhaus K, Deng P, Kriegl JM, et al.: Structural dynamics of myoglobin: spectroscopic and structural characterization of ligand docking sites in myoglobin mutant L29W. Biochemistry. 2003; 42(32): 9633-9646. PubMed Abstract | Publisher Full Text

34. Lehle $\mathrm{H}$, Kriegl JM, Nienhaus $\mathrm{K}$, et al:: Probing electric fields in protein cavities by using the vibrational stark effect of carbon monoxide. Biophys J. 2005 88(3): 1978-1990.

PubMed Abstract | Publisher Full Text | Free Full Text

35. Nienhaus K, Maes EM, Weichsel A, et al:: Structural dynamics controls nitric oxide affinity in nitrophorin 4. J Biol Chem. 2004; 279(38): 39401-39407. PubMed Abstract | Publisher Full Tex

36. Lim M, Jackson TA, Anfinrud PA: Ultrafast rotation and trapping of carbon monoxide dissociated from myoglobin. Nat Struct Biol. 1997; 4(3): 209-214. PubMed Abstract | Publisher Full Text

37. Bredenbeck J, Helbing J, Nienhaus $\mathrm{K}$, et al:: Protein ligand migration mapped by nonequilibrium 2D-IR exchange spectroscopy. Proc Natl Acad Sci U S A. 2007; 104(36): 14243-14248.

PubMed Abstract | Publisher Full Text | Free Full Text

38. Nienhaus $\mathrm{K}$, Knapp JE, Palladino $\mathrm{P}$, et al:: Ligand migration and binding in the dimeric hemoglobin of Scapharca inaequivalvis. Biochemistry. 2007; 46(49): 14018-14031.

PubMed Abstract | Publisher Full Text | Free Full Text

39. Nienhaus GU, Heinzl J, Huenges E, et al:: Protein Crystal Dynamics Studied by Time-resolved Analysis of X-ray Diffuse Scattering. Nature. 1989; 338: 665-666. Publisher Full Text

40. Frauenfelder H, Nienhaus GU, Johnson JB: Rate Processes in Proteins. Ber Bunsenges Phys Chem. 1991; 95(3): 272-278.

Publisher Full Text

41. Berendzen J, Braunstein D: Temperature-derivative spectroscopy: a tool for protein dynamics. Proc Natl Acad Sci U S A. 1990; 87(1): 1-5.

PubMed Abstract | Publisher Full Text | Free Full Text
42. Nienhaus GU, Mourant JR, Chu K, et al.: Ligand binding to heme proteins: the effect of light on ligand binding in myoglobin. Biochemistry. 1994; 33(45) 13413-13430

PubMed Abstract | Publisher Full Text

43. Mourant JR, Braunstein DP, Chu K, et al.: Ligand binding to heme proteins: II. Transitions in the heme pocket of myoglobin. Biophys J. 1993; 65(4): 1496-1507. PubMed Abstract | Publisher Full Text | Free Full Text

44. Ghosh DK, Wu C, Pitters E, et al.: Characterization of the inducible nitric oxide synthase oxygenase domain identifies a 49 amino acid segment required for subunit dimerization and tetrahydrobiopterin interaction. Biochemistry. 1997; 36(35): 10609-10619.

PubMed Abstract | Publisher Full Text

45. Jung C, Stuehr DJ, Ghosh DK: FT-Infrared spectroscopic studies of the iron ligand $\mathrm{CO}$ stretch mode of iNOS oxygenase domain: effect of arginine and tetrahydrobiopterin. Biochemistry. 2000; 39(33): 10163-10171.

PubMed Abstract | Publisher Full Text

46. Li D, Stuehr DJ, Yeh SR, et al:: Heme distortion modulated by ligand-protein interactions in inducible nitric-oxide synthase. J Biol Chem. 2004; 279(25): 26489-26499

PubMed Abstract | Publisher Full Text

47. Crane BR, Arvai AS, Ghosh S, et al.: Structures of the N(omega)-hydroxy-Larginine complex of inducible nitric oxide synthase oxygenase dimer with active and inactive pterins. Biochemistry. 2000; 39(16): 4608-4621.

PubMed Abstract | Publisher Full Text

48. Fukuto JM: Chemistry of N-hydroxy-L-arginine. Methods Enzymol. 1996; 268 365-375.

PubMed Abstract | Publisher Full Text

49. Tantillo DJ, Fukuto JM, Hoffman BM, et al:: Theoretical studies on $\mathbf{N}-\gamma$-hydroxyL-arginine and derived radicals: Implications for the mechanism of nitric oxide synthase. J Am Chem Soc. 2000; 122(3): 536-537. Publisher Full Text

50. Labby KJ, Li HY, Roman LJ, et al.: Methylated N- $\omega$-Hydroxy-L-arginine Analogues as Mechanistic Probes for the Second Step of the Nitric Oxide Synthase-Catalyzed Reaction. Biochemistry. 2013; 52(18): 3062-3073. PubMed Abstract | Publisher Full Text | Free Full Text

51. Lamb DC, Nienhaus K, Arcovito A, et al:: Structural dynamics of myoglobin: ligand migration among protein cavities studied by Fourier transform infrared/ temperature derivative spectroscopy. J Biol Chem. 2002; 277(14): 11636-11644. PubMed Abstract | Publisher Full Text

52. Nienhaus K, Lamb DC, Deng $P$, et al.: The effect of ligand dynamics on heme electronic transition band III in myoglobin. Biophys J. 2002; 82(2): 1059-1067. PubMed Abstract | Publisher Full Text | Free Full Text

53. Scott EE, Gibson QH, Olson JS: Mapping the pathways for $\mathrm{O}_{2}$ entry into and exit from myoglobin. J Biol Chem. 276(7): 5177-5188 PubMed Abstract | Publisher Full Text

54. Nienhaus K, Deng $\mathrm{P}$, Olson JS, et al:: Structural dynamics of myoglobin: ligand migration and binding in valine 68 mutants. J Biol Chem. 2003; 278(43): 42532-42544

PubMed Abstract | Publisher Full Text

55. Nienhaus $\mathrm{K}$, Zosel F, Nienhaus GU: Ligand binding to heme proteins: a comparison of cytochrome c variants with globins. J Phys Chem B. 2012 116(40): 12180-12188.

PubMed Abstract | Publisher Full Text

56. Nienhaus K, Palladino P, Nienhaus GU: Structural dynamics of myoglobin: FTIRTDS study of NO migration and binding. Biochemistry. 2008; 47(3): 935-948. PubMed Abstract | Publisher Full Text

57. Soldatova AV, Ibrahim M, Olson JS, et al:: New light on NO bonding in $\mathrm{Fe}$ (III) heme proteins from resonance Raman spectroscopy and DFT modeling. J Am Chem Soc. 132(13): 4614-4625.

PubMed Abstract | Publisher Full Text | Free Full Text

58. Praneeth VK, Paulat F, Berto TC, et al.: Electronic structure of six-coordinate ron(III)-porphyrin NO adducts: the elusive iron(III)-NO(radical) state and its influence on the properties of these complexes. J Am Chem Soc. 2008; 130(46): 15288-15303.

PubMed Abstract | Publisher Full Text

59. Batabyal D, Yeh SR: Human tryptophan dioxygenase: a comparison to indoleamine 2,3-dioxygenase. J Am Chem Soc. 2007; 129(50): 15690-15701. PubMed Abstract | Publisher Full Text

60. Xu N, Powell DR, Cheng L, et al.: The first structurally characterized nitrosyl heme thiolate model complex. Chem Commun (Camb). 2006; (19): 2030-2032. PubMed Abstract | Publisher Full Text

61. Obayashi E, Tsukamoto K, Adachi S, et al.: Unique binding of nitric oxide to ferric nitric oxide reductase from Fusarium oxysporum elucidated with infrared, resonance Raman, and X-ray absorption spectroscopies. J Am Chem Soc. $1997 ;$ 119: 7807-7816. Publisher Full Text

62. Li H, Igarashi J, Jamal J, et al.: Structural studies of constitutive nitric oxide synthases with diatomic ligands bound. J Biol Inorg Chem. 2006; 11(6): 753-768. PubMed Abstract | Publisher Full Text

63. McQuarters AB, Wirgau NE, Lehnert N: Model complexes of key intermediates in fungal cytochrome P450 nitric oxide reductase (P450nor). Curr Opin Chem Biol. 2014; 19: 82-89.

PubMed Abstract | Publisher Full Text 
64. Shimizu H, Obayashi E, Gomi Y, et al.: Proton delivery in NO reduction by fungal nitric-oxide reductase. Cryogenic crystallography, spectroscopy, and kinetics of ferric-NO complexes of wild-type and mutant enzymes. J Biol Chem. 2000; 275(7): 4816-4826.

PubMed Abstract | Publisher Full Text

65. Pant K, Crane BR: Nitrosyl-heme structures of Bacillus subtilis nitric oxide synthase have implications for understanding substrate oxidation. Biochemistry. 2006; 45(8): 2537-2544.

PubMed Abstract | Publisher Full Text

66. Goodrich LE, Paulat F, Praneeth VK, et al.: Electronic structure of heme-nitrosyls and its significance for nitric oxide reactivity, sensing, transport, and toxicity in biological systems. Inorg Chem. 2010; 49(14): 6293-6316. PubMed Abstract | Publisher Full Text

67. Couture M, Adak S, Stuehr DJ, et al.: Regulation of the properties of the hemeNO complexes in nitric-oxide synthase by hydrogen bonding to the proximal cysteine. J Biol Chem. 2001; 276(41): 38280-38288. PubMed Abstract | Publisher Full Text

68. Rousseau DL, Li D, Hayden EY, et al.: Chapter 17 - Ligand-Protein Interactions in Mammalian Nitric Oxide Synthase. in The Smallest Biomolecules: Diatomics and their Interactions with Heme Proteins (Ghosh, A. ed.), Elsevier, Amsterdam. 2008; 465-497.

Publisher Full Text

69. Hu SZ, Kincaid JR: Resonance Raman Spectra of the Nitric Oxide Adducts of Ferrous Cytochrome P450cam in the Presence of Various Substrates. J Am Chem Soc. 1991; 113(26): 9760-9766. Publisher Full Text

70. Praneeth VK, Haupt E, Lehnert N: Thiolate coordination to Fe(II)-porphyrin NO centers. J Inorg Biochem. 2005; 99(4): 940-948. PubMed Abstract | Publisher Full Text

71. Li D, Hayden EY, Panda K, et al.: Regulation of the monomer-dimer equilibrium in inducible nitric-oxide synthase by nitric oxide. J Biol Chem. 2006; 281(12): 8197-8204.

PubMed Abstract | Publisher Full Text

72. Abu-Soud HM, Wu C, Ghosh DK, et al:: Stopped-flow analysis of $\mathrm{CO}$ and NO binding to inducible nitric oxide synthase. Biochemistry. 1998; 37(11): 3777-3786. PubMed Abstract | Publisher Full Text

73. Wang J, Rousseau DL, Abu-Soud HM, et al: Heme coordination of NO in NO synthase. Proc Natl Acad Sci U S A. 1994; 91(22): 10512-10516. PubMed Abstract | Publisher Full Text | Free Full Text
74. Ibrahim M, Xu CL, Spiro TG: Differential sensing of protein influences by NO and CO vibrations in heme adducts. J Am Chem Soc. 2006; 128(51): 16834-16845.

PubMed Abstract | Publisher Full Text | Free Full Text

75. Coyle CM, Vogel KM, Rush TS 3rd, et al.: FeNO structure in distal pocket mutants of myoglobin based on resonance Raman spectroscopy. Biochemistry. 2003; 42(17): 4896-4903.

PubMed Abstract | Publisher Full Text

76. Chiavarino B, Crestoni ME, Fornarini S, et al.: Direct probe of NO vibration in the naked ferric heme nitrosyl complex. Chemphyschem. 2008; 9(6): 826-828. PubMed Abstract | Publisher Full Text

77. Lanucara F, Chiavarino B, Crestoni ME, et al.: Naked five-coordinate Fe(III)(NO) porphyrin complexes: vibrational and reactivity features. Inorg Chem. 2011; 50(10): 4445-4452.

PubMed Abstract | Publisher Full Text

78. Dey A, Okamura TA, Ueyama N, et al.: Sulfur K-edge XAS and DFT calculations on P450 model complexes: effects of hydrogen bonding on electronic structure and redox potentials. J Am Chem Soc. 2005; 127(34): 12046-12053. PubMed Abstract | Publisher Full Text | Free Full Text

79. Decatur SM, Franzen S, DePillis GD, et al.: Trans effects in nitric oxide binding to myoglobin cavity mutant H93G. Biochemistry. 1996; 35(15): 4939-4944. PubMed Abstract | Publisher Full Text

80. Fernandez ML, Marti MA, Crespo A, et al.: Proximal effects in the modulation of nitric oxide synthase reactivity: a QM-MM study. J Biol Inorg Chem. 2005; 10(6): 595-604.

PubMed Abstract | Publisher Full Text

81. Linder DP, Rodgers KR, Banister J, et al:: Five-coordinate $\mathrm{Fe}$ (III)NO and $\mathrm{Fe}$ (II)CO porphyrinates: where are the electrons and why does it matter? J Am Chem Soc. 2004; 126(43): 14136-14148. PubMed Abstract | Publisher Full Text | Free Full Text

82. Huang L, Abu-Soud HM, Hille R, et al.: Nitric oxide-generated P420 nitric oxide synthase: characterization and roles for tetrahydrobiopterin and substrate in protecting against or reversing the $\mathbf{P} 420$ conversion. Biochemistry. 1999; 38(6): 1912-1920.

PubMed Abstract | Publisher Full Text

83. Horn M, Nienhaus K, Nienhaus GU: Fourier transform infrared photolysis difference spectra of $\mathrm{CO}$ - and NO-ligated inducible nitric oxide synthase. F1000Research. 2014

Data Source 


\section{Open Peer Review}

\section{Current Peer Review Status:}

\section{Version 1}

Reviewer Report 05 December 2014

https://doi.org/10.5256/f1000research.6238.r6849

(C) 2014 Schmidt $\mathbf{M}$. This is an open access peer review report distributed under the terms of the Creative Commons Attribution License, which permits unrestricted use, distribution, and reproduction in any medium, provided the original work is properly cited.

\section{Marius Schmidt}

Department of Physics, University of Wisconsin-Milwaukee, Milwaukee, WI, USA

This is a very interesting investigation on protein ligand interaction in iNOS. It is well written and informative. It should be indexed, and requires only minor revisions.

p. 6 text: "In substrate free iNOSoxy-CO, recombination is already maximal at $4 \mathrm{~K}$ and extends to $\sim 70 \mathrm{~K} . "$

What does this mean? What is a maximal recombination?

Suggestion: "there is already substantial recombination at $4 \mathrm{~K}$ and the process extends to 70 K."

p. 6 text: "A population transfer between photoproduct states due to CO rotation 32,51,52 is apparent from the mirror-imaged dashed and solid contours at 2131 and $2144 \mathrm{~cm}-1$ at 12 K".

Just write a sentence or two why that is so. The non-expert reader should not read the literature for this.

Figure 3, caption: there is a mix-up with panel numbers.

The case for a $5 \mathrm{C}$ and the $4 \mathrm{C}$ (naked) heme is well made. This is a very interesting result and merits closer investigation by $\mathrm{X}$-ray structure determination.

Competing Interests: No competing interests were disclosed.

I confirm that I have read this submission and believe that I have an appropriate level of expertise to confirm that it is of an acceptable scientific standard. 
Reviewer Report 05 December 2014

https://doi.org/10.5256/f1000research.6238.r6853

(c) 2014 Ormos P. This is an open access peer review report distributed under the terms of the Creative Commons Attribution License, which permits unrestricted use, distribution, and reproduction in any medium, provided the original work is properly cited.

\section{Pál Ormos}

Institute of Biophysics, Biological Research Centre of the Hungarian Academy of Sciences, Szeged, Hungary

It is investigated how ligands $\mathrm{NO}$ and $\mathrm{CO}$ dissociate and bind to inducible nitric oxide synthase. The applied method is FTIR difference spectroscopy, in particular low temperature temperature derivative spectroscopy, most appropriate to elucidate details of the process. The binding route has been clarified and compared to related ligand binding heme proteins. The results are important in characterizing the enzyme. As I understand, the task of the referee is primarily to judge the soundness, the technical quality of the work. There is absolutely no problem in this respect: the method is appropriate, executed perfectly, the conclusions are well supported. I suggest indexing without any modification.

Competing Interests: No competing interests were disclosed.

I confirm that I have read this submission and believe that I have an appropriate level of expertise to confirm that it is of an acceptable scientific standard.

The benefits of publishing with F1000Research:

- Your article is published within days, with no editorial bias

- You can publish traditional articles, null/negative results, case reports, data notes and more

- The peer review process is transparent and collaborative

- Your article is indexed in PubMed after passing peer review

- Dedicated customer support at every stage

For pre-submission enquiries, contact research@f1000.com

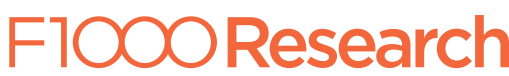

